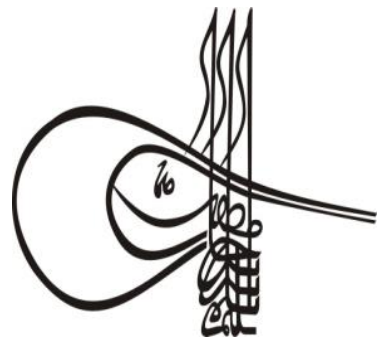

Received/Geliş: 17.08 .2019

\section{Turkigh Studies}

Volume 14 Issue 6, 2019, p. 3409-3432

DOI: 10.29228/TurkishStudies.30248

ISSN: $1308-2140$

Skopje/MACEDONIA-Ankara/TURKEY

Research Article / Araștırma Makalesi

Article Info/Makale Bilgisi

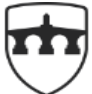

INTERNATIONAL BALKAN UNIVERSITY

EXCELLENCE FOR THE FUTURE IBU.EDU.MK

$\checkmark$ Accepted/Kabul: 15.10 .2019

Go Report Dates/Rapor Tarihleri: Referee 1 (22.08.2019)-Referee 2 (29.09.2019)

This article was checked by iThenticate.

\title{
VAN ABBAS AĞA CAMİİ KAZI-KORUMA VE UYGULAMA PROJESİ ÜZERİNE BİR ARAŞTIRMA
}

\author{
Şahabettin ÖZTÜRK
}

\section{öz}

Eski Van Şehri'nin kuzeybatı bölümünde yer alan Abbas Ağa Camii, günümüzde büyük bir bölümü yıkık durumdadır. Abbas Ağa Camii'nin hangi tarihte ve kim tarafından inşa edildiği bilinmemektedir. Yapının inşa malzemesi, tekniği ve mimari formu dikkate alındığında XIX. yüzyıl sonunda inşa edildiği düşünülmektedir.

1915 yılına kadar kullanılan yapının, 1918'den sonra düz toprak örtü sistemi tamamen yıkılmış, diğer bölümleri ise doğanın ve definecilerin olumsuz etkisine rağmen, kısmen de olsa ayakta kalma mücadelesini vermektedir. Yapının iç mekânı 9.10x18.75 m. ölçülerinde enine planlı olarak inşa edilmiștir. Yapıyı oluşturan beden duvarları zemin seviyesinden yaklaş1k $2.00 \mathrm{~m}$. moloz taş örgülü diğer bölümleri ise tamamıla kerpiç malzeme kullanılarak inşa edilmiştir.

2013 yılında yapılan bilimsel kazı çalışmaları ile yapının zemin kodu, mahfil katı, kemer ayaklarının üzerine oturduğu iki adet yonu taş kaide, mihrap nişi, minber kaidesi, oturma sekileri tespit edilmiştir. Cami diş çevresinde yapilan kazılar ile avlu elemanları, su kuyusu ve sokak dokusu ortaya çıkmıştır. Kazılar sonucunda ortaya çıkan tüm yeni verilerin Yüzüncü Y1l Üniversitesi Mühendislik ve Mimarlık Fakültesi Mimarlık Bölümü Restorasyon Anabilim Dalı Başkanlığı tarafından koruma amaçlı rölöve, restitüsyon, restorasyon uygulama projeleri yeniden hazırlanmıștır. Vakıflar Bitlis Bölge Müdürlüğü tarafından yapının onarım çalışmaları devam etmektedir.

Abbas Ağa Camii, kerpiç malzeme, çamur sıva yardımıyla inşa edilen beden duvarlarının iç bölümlerine yerleştirilen aks-i seda küpleri, düz toprak dam sistem ve yapım teknikleri bakımından bölgedeki diğer dini mimari yapılardan oldukça farklı mimari özelliklere sahiptir. 
Anahtar Kelimeler: Kerpiç, Bat, Çamur, Ahşap Hatıl, Oturma Sekileri, Aks-i Seda Küpleri

\title{
A RESEARCH ON THE EXCAVATION, PROTECTION- CONSERVATION AND APLICATION PROJECT OF THE VAN ABBAS AGA MOSQUE
}

\begin{abstract}
Abbas Aga Mosque which is located in the northwestern part of the Old Van City is in a ruinous condition currently. It is not known for certain when and by whom Abbas Aga Mosque was built. Considering the building's construction materials, technique and the form, it is assumed that it was built at the end of the XIXth century.

Flat roof covering system of the building which was used until the year of 1915 was ruined after 1918 and other parts are tried to survive in spite of the nature's and treasure hunters' negative effects. Interior space of the building was built in approximately $9.10 \times 18.75 \mathrm{~m}$. sizes, cross planned. Entrance of the mosque is through a door of $1.58 \mathrm{~m}$. width from the north. Approximately $2 \mathrm{~m}$ of the frames forming the building are rubble stoned and other parts are completed with using mud-brick materials thoroughly.

The building's floor level, gathering place story, two pedestals where abutments settle, altar niche, pulpit base and settling styles have been observed during the scientific excavation works in 2013. Yard components and the street pattern were appeared after excavations which were done in surounding areas of the mosque. Application projects of survey, restitution and were prepared upon all new data coming out of the excavations. Renovation works are continued by Foundations Directory's Bitlis Regional Office.

Abbas Aga Mosque varies in terms of architectural qualities from other religious buildings in the region from the aspects of aks-i seda küpleri (echo cubes) which were put in the inside parts of the frame walls which were made out of mud-brick materials and clay and flat soil roof system and construction techniques.
\end{abstract}

\section{STRUCTURED ABSTRACT}

The Old City of Van which is located at south Van has been used by many civilizations since Urartians until today. The city is surrounded by historical walls on the east, south and west and by Van Castle's sharp rocks on the north. Today Old Van is almost a decayed city losing its former liveliness and mobility since 1918. Current architectural buildings in the city have been estreping to the ground everyday blatantly because of neglect, disrepair and disrespect to the past. In spite of all these negativities, Abbas Agha Mosque is one of the registered historical religious buildings struggling to survive. The mosque's built date and builders are unknown. Regarding its 
construction technique and architectural form, it is thought that it was built at the end of the XIXth century.

The Mosque's excavation, cleaning and renovation works are put out to tender by Bitlis Regional Directory of Foundations in the year 2013 and the process started. Surveying, excavation and cleaning works in and around of the Mosque are performed in approximately two months by skilled workers and builders under the technical inspection of the project's author, constractor company's technical staff and the foundation. Southern road ground level and architectural covering pattern, northern entrance's mortar stones, a water well, the courtyard's floor ground level and many other architectural elements are located during excavation and cleaning works outside of the building. Their architectural features are defined. On excavation and cleaning works, many pots and pans, tiles, ceramics, metal elements, wooden amorphous pieces in the excavation soil are classified separately.

Abbas Agha Mosque is accessed through a double leaf wooden door in an ogee arch alcove in the middle of the north main outer wall. Interior space is formed by a rectangular layout plan developed on the east-west direction. There is the altar alcove in the middle of the south main outer wall on the entry door axle.

The mosque is separated into two sections in east-west directions by three ogee arches which are put on the pedestals and two abutments made out of square-shaped freestones in similar architectural features. Access is provided to the wooden gathering place level with one-handle wooden stairs that adjacent and parallel built to the north main outer wall in the east of entrance gate. Wooden gathering place proceeds in north main outer wall.

In order to arrange the sound inside of the mosque, many echo cubes (aks-i seda küpleri) are placed inside of the outer walls. All outer walls of the building ascends by rubble stone to a particular level and proceeds as mudbrick; then pass to the flat soil roof is enabled. East and south streets of Abbas Agha Mosque are rubble paved. Entrance to the mosque's slate stone floor courtyard is accessed from a gate in east. The courtyard that is located in north of the building is planned as quite wide and two- stage.

Double leaf wooden entrance door in the middle of the north front is formed in an ogee arche. Two windows are located on both sides of the entrance door as symmetrically placed in ogee arches. A total of nine windows on the lower and upper parts of the south front are located on the same axles providing mobility to the front. Two top windows located on the east and west fronts are lined on the same horizntal axle for another mobility to the front. Upper two windows of the western front are located on the same axle providing mobility to the front as well.

Abbas Agha Mosque's flat soil roof is sloped in the north and south direction. Three different construction techniques are applied on outer walls. The building is structured by rubble masonry rock fill technique up to a particular level from ground, by traditional mud-brick 
arrangement technique until flat soil roof level and by coursed smooth face stone inside of the arches.

Rubble, freestone, slate, mud-brick, brick, metal and wood are used for Abbas Agha Mosque's construction. Lime mortar is used as binding material for the building's stone wall construction. Wood ash, chaff and rock salt added clay parget are used as binding materials in mud-brick walls. Analysis for the building's pargets and mortars have been performed and the report is completed by Istanbul Restoration and Conservation Center and Regional Laboratory Directory. Abbas Agha Mosque is highly plain in terms of its internal and external elements. All architectural data revealed after excavation and cleaning works have been revised and projects are reprepared by lecturer Dr. Şahabettin Öztürk, Restoration Programme Director of the Architecture Department at the Yüzüncü Yil University's Faculty of EngineeringArchitecture.

Abbas Agha Mosque is a building that not only had been used as a mosque, also as a madrassah at the same time. Especially freestone sitting berms in the mosque reveal as an exceptional architectural element. It proves that the mosque was not meant only for worship, but rather also for social activities.

Scientific excavation works in the Old City of Van and north of the Van Castle which are done only once in a year, for one month, have been disappearing under the negative impacts of nature and treasure hunters in recent years. It is a fact that buildings particularly such as Abbas Agha Mosque, Ulu (Great) Mosque, Kiz1l (Red) Mosque those of renovation works have been in proceed, are going to provide vitality after approximately one century to the Old City of Van, after the renovations are completed. This case will provide important gains to the region's culture and tourism.

Keyword: Mud-brick, Bat, Clay, Timber, Settling Styles, Aks-i Seda Küpleri (Echo Cubes)

\section{Giriş}

Van Kalesi'nin güneyinde yer alan Eski Van Şehri yaklaşık $365.000 \mathrm{~m}^{2}$ lik alan üzerine kurulu olup, Urartulardan günümüze kadar birçok uygarlık tarafindan kullanılmıştır. Şehrin doğu, güney ve batısı tarihi surlarla kuzeyi ise Van Kalesi yalçın kayalıkları ile çevrilidir. Şehre giriş surlarda açılan dört ana kapı ile sağlanmaktadır. Bunlardan doğu surlarının kuzey köşesindeki Tebriz Kapısı, batı surlarının kuzey köşesindeki Yalı (İskele) Kapısıdır. Diğer iki kapı ise güney surlarının üzerinde yer alan Orta Kapı(Yeni Kapı) ile Saray (Ŭgrun) Kapısı'dır (Öztürk ve Mızrak 2001: 32-34), (Şekil 1). 


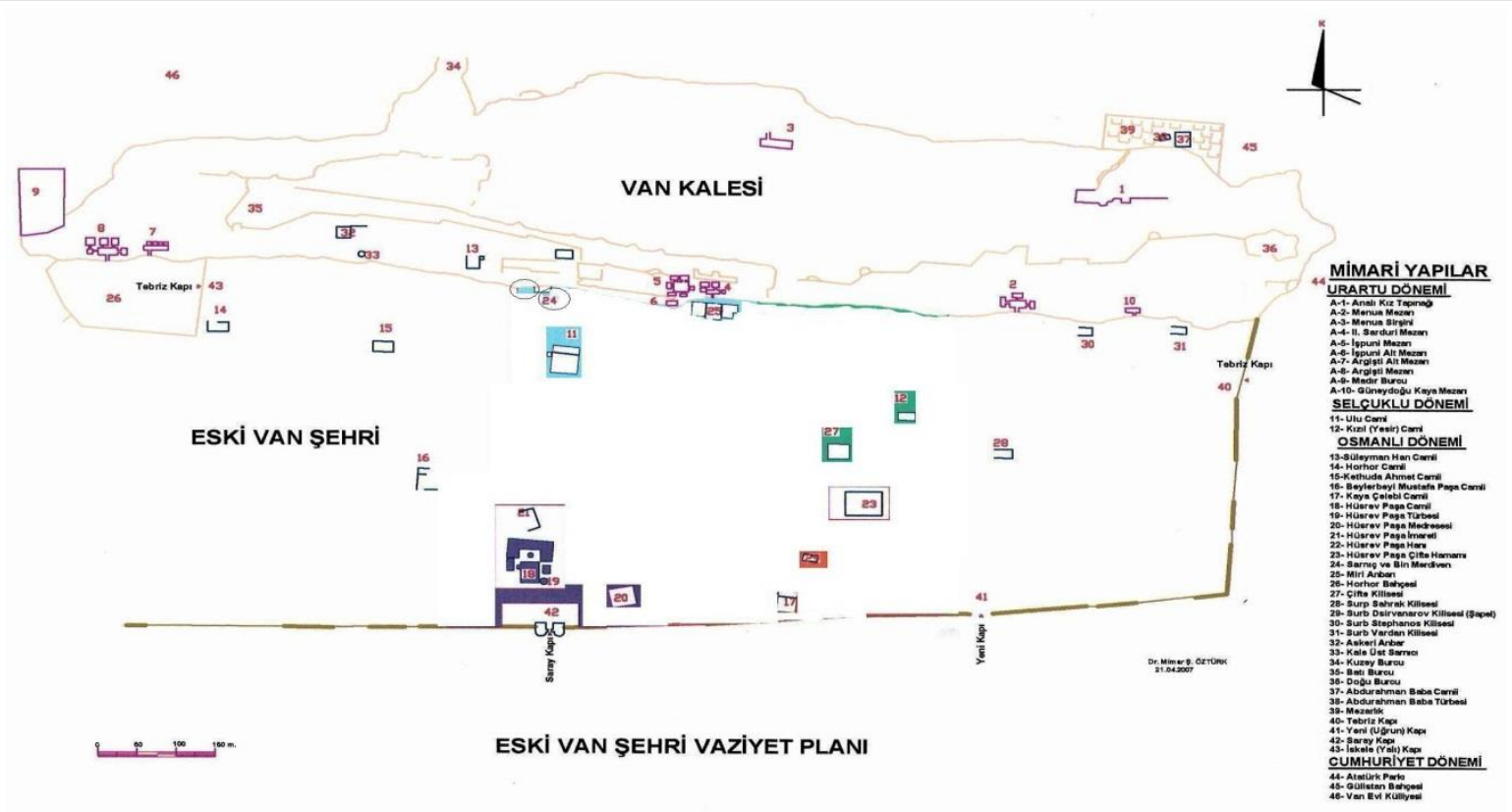

Şekil 1. Eski Van Şehir Vaziyet Planı (Ş. Öztürk)

H.1245 yılında Ahlat Kalesi'ndeki top ve mühimmatın gemilerle Van Kalesi'ne nakli ile şehrin öneminin artmasından dolayı şehir surlarının yeniden onarımı yapılmıştır. Onarım kitabesi Orta(Yeni) Kapı üzerindedir. Eski Van Şehri, topoğrafik olarak az eğimli bir yapıya sahiptir. Şehirde Türklerle Ermeniler yan yana iyi komşuluk ilişkisi içinde yıllarca birlikte kardeşçe yaşamıştır (Şekil $1)$.

Topkapı Sarayı Arşivi’ndeki (E.9487) XVII. yüz yılda hazırlanan minyatür Van Kalesi ve şehrinin gerçeğe yakın genel görünümü hakkında bilgi vermektedir. Eski fotoğraflar ve gravürlerden görüldüğü gibi Van Şehri her türden ve dinden mimarinin iç içe olduğu bir kent yapısındadır. XVII.(1655) yüzyılın ortalarında bölgeyi gezen Evliya Çelebi, şehrin 10 mahallesinin olduğunu, büyük çoğunluğunu Müslümanların oluşturduğu şehrin üç mahallesinde ise Ermenilerin oturduğunu anlatmıştır. XIX. yüzyılın son çeyreğinde Lynch tarafından hazırlanan haritada şehrin on iki mahalleden oluştuğu bu mahallelerden dokuzunun Müslüman, üçünün ise gayrimüslimlerden meydana geldiği görülmektedir (Günel, 41-48: 1993).

1914'te I. Dünya Savașı ile Avrupa'da başlayan milliyetçilik akımları Osmanlı topraklarında yaşayan Ermenileri de etkilemiştir. 2 Nisan 1918'de Ali Sinan (Sabis) Paşa komutasındaki 4. Kolordu'nun Van'a girmesiyle üç y1llık işgal son bulur. Bu tarihten sonra Van'dan göç eden yerli halkın bir bölümü geri dönmüştür. Özellikle 1877-1878 Osmanl1-Rus savaşından (93 Harbi) sonra Ermeni çetelerin örgütlendiği ilk kentlerden biri Van'dır. 17 Mart 1915'de sayıları 4.000 olan Ermeni Taşnak çeteleri Van Şehri'ni Rus birliklerle işgal eder. 


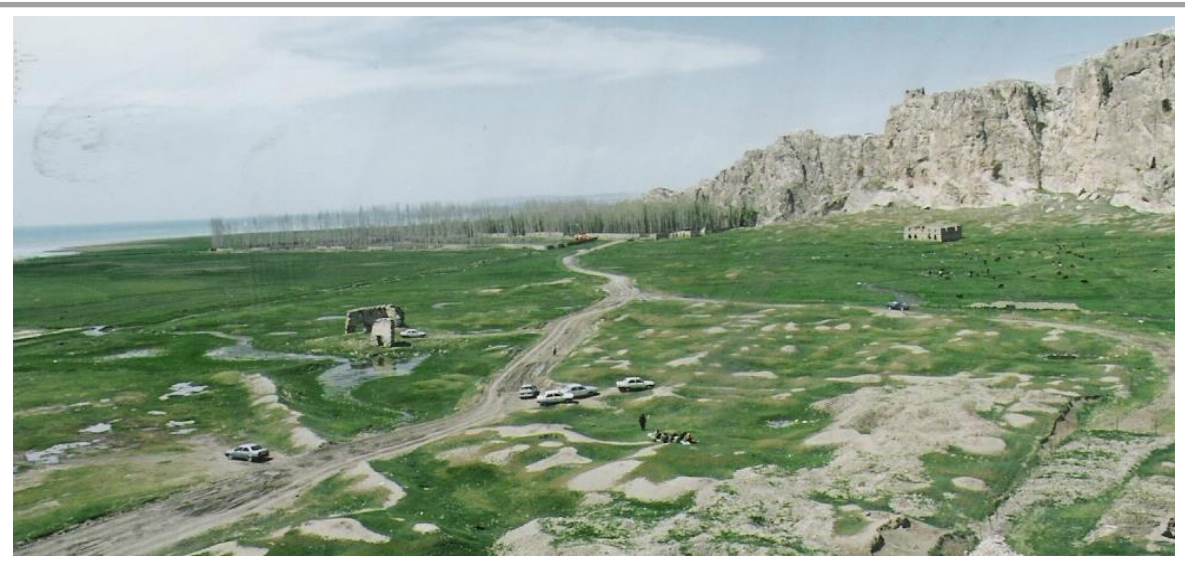

Şekil 2. Eski Van Şehri Genel Görünüşü (Ş. Öztürk)

1917'de Rusya'da Çarlık rejimi yıkılmış, yerine gelen Bolşevik Partisi, 18 Aralık 1918'de Erzincan'da yapılan anlaşma gereğince, Rus birlikleri Doğu Anadolu Bölgesi'nden geri çağrılmıştır. Şehrin konumu yeniden yapılanmasına imkân vermediği için, halk şehrin dışında kalan bahçe ve bağ evlerine yerleşerek günümüz Van Şehri'nin bir nevi temellerini oluşturmuşlardır. 1918 yılından sonra eski canlılık ve hareketliliğini kaybeden Eski Van Şehri adeta bir ölü şehir konumuna gelmiştir (Öztürk, Ş. 2004: 52-54).

Eski Van Şehri'ndeki mevcut mimari yapılar ilgisizlik, bakımsızlık ve geçmişe saygısızlıktan göz göre göre her gün biraz daha zemine yaklaşarak kaybolmaktadır. Bütün bu yaşanan olumsuzluklara rağmen ayakta kalma mücadelesini veren tarihi tescilli dini yapılarından biri ise Abbasağa Cami'sidir (Şekil 1-3).

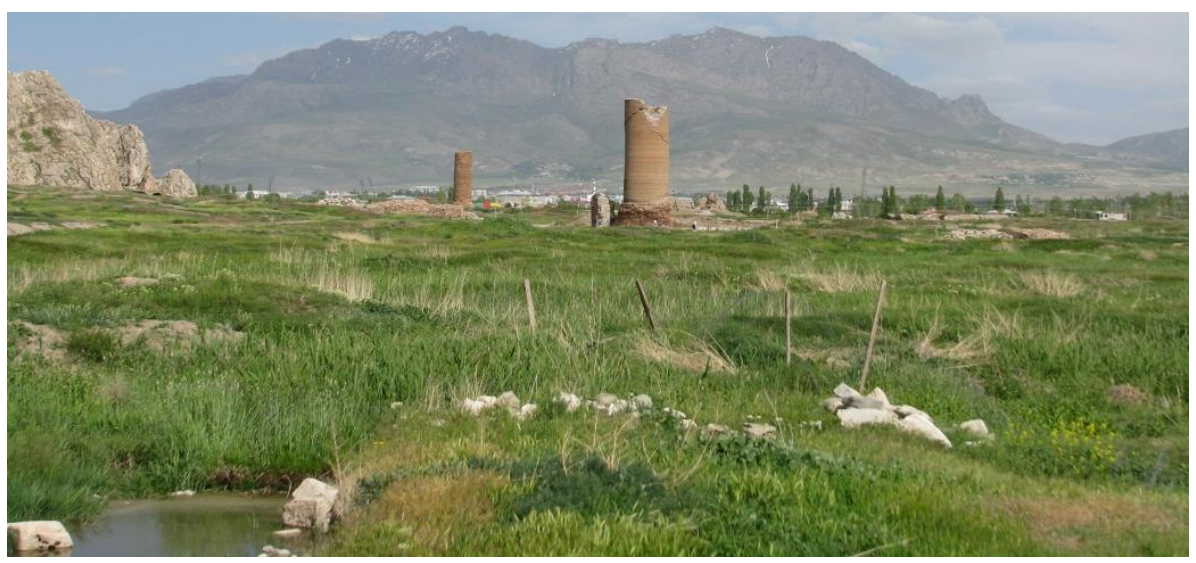

Şekil 3. Eski Van Şehri Genel Görünüşü (Ş. Öztürk)

Yapıya ait tüm mimari koruma proje ve raporlar, Yüzüncü Yıl Üniversitesi Mühendislik ve Mimarlık Fakültesi Mimarlık Bölümü Restorasyon Anabilim Dalı Başkanı Dr. Öğretim Üyesi Şahabettin Öztürk tarafından yapılarak 2014 yılı içerisinde tamamlanmıştır. 


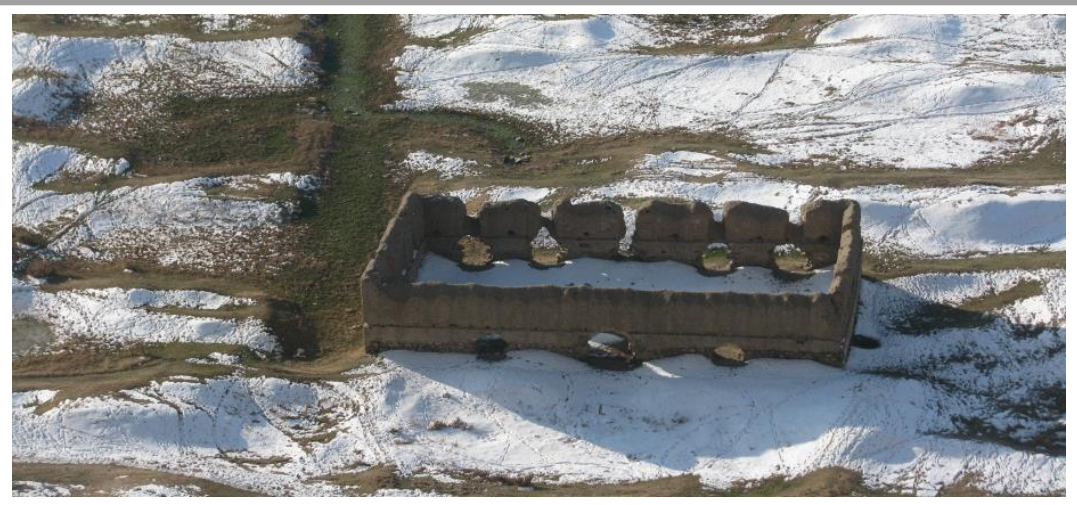

Şekil 4. Abbas Ağa Camii Genel Görünüşü (Ş. Öztürk)

\section{Konumu}

Eski Van Şehri'nde yer alan tarihi Abbasağa Camii, şehrin kuzeybatısında orta eğimli bir alanda dikdörtgen formunda doğu-batı istikametinde zemine kurulmuştur.

Abbasağa Camii'nin batısında Horhor Cami, doğusunda Van Ulu Cami, kuzeyinde ise tarihi Van Kalesi yer almaktadır (Şekil 1-4). Vakıflar Bitlis Bölge Müdürlüğü tarafından 2013 yılında yüklenici firma kalifiye elemanlarına proje müellifi ve kurum teknik elemanlarının denetiminde yapılan kazı ve temizlik çalışmaları ile tarihi yapıya ait tüm mimari iz ve veriler ortaya çıkarılmıştır.

Günümüzde yapının örtü sistemini tamamı beden duvarları ve kuzey giriş bölümünde yer alan avlu ve su kuyusu gibi birçok mimari eleman yok olmuştur.

\section{Tarihçesi}

Abbasağa Camii'nin hangi tarihte ve kim tarafından inşa edildiği tam olarak bilinmemektedir. Yapının inşa malzemesi, yapım tekniği ve mimari formu dikkate alındığında, XIX yüzyıl sonunda inşa edildiği düşünülmektedir (Öztürk, 8: 1996).

Kültür ve Turizm Bakanlığ Diyarbakır Kültür ve Tabiat Varlıklarının Koruma Bölge Kurulu Müdürlüğ̈̈'nce 08.06.1979/A-1673 tarihli toplantıda yapıya ait mevcut bilgiler görüşülmüsş, 2863 ve 3386 sayılı yasalar uyarınca korunması gerekli kültür varlığı özelliği gösterdiğinden tesciline karar verilmiştir. Koruma Projesi Van Valiliği İl Kültür ve Turizm Müdürlüğü tarafindan önerilen, İl Özel İdare Sekreterliği'nin 2008 yılındaki proje yatırım çalışmaları kapsamında değerlendirilmiştir. $\mathrm{Bu}$ kapsamda yapının rölöve-restitüsyon ve restorasyon projesi hazırlanarak, projeler Van Kültür Varlıklarının Koruma Bölge Kurulu tarafından 2010 yılında onaylanmıştır.

Bitlis Vakıflar Bölge Müdürlüğ̈̈ ve Van Valiliği ile 2010 yılında yapılan bir protokol ile Abbas Ağa Camii mülkiyeti Vakıflar Bitlis Bölge Müdürlüğü mülkiyetine devredilmiştir. Bitlis Vakıflar Bölge Müdürlüğü 2013 yılında yapının restorasyon çalışmalarının ilgili yüklenici firma tarafından kazı çalışmalarında ortaya çıkan yeni veriler ile onaylanan projelere işlenerek revizyon çalışmaları yapılmıştır.

\section{Kazı ve Temizlik Çalışmaları}

Bitlis Vakıflar Bölge Müdürlüğü tarafından Abbas Ağa Camii, kazı, temizlik onarım çalışmaları 2013 yılında ihale edilerek, çalışmalar hemen başlatılmıştır. Cami iç mekân ve çevresinde yapılan araştırma kazısı ve temizlik çalışmaları, kalifiye işçi, ustalar proje müellifi, yüklenici firma teknik elemanlar ve Vakıflar Bitlis Bölge Müdürlüğü'nün teknik denetiminde yaklaşık iki ay içerisinde yapılarak tamamlanmıştır. 


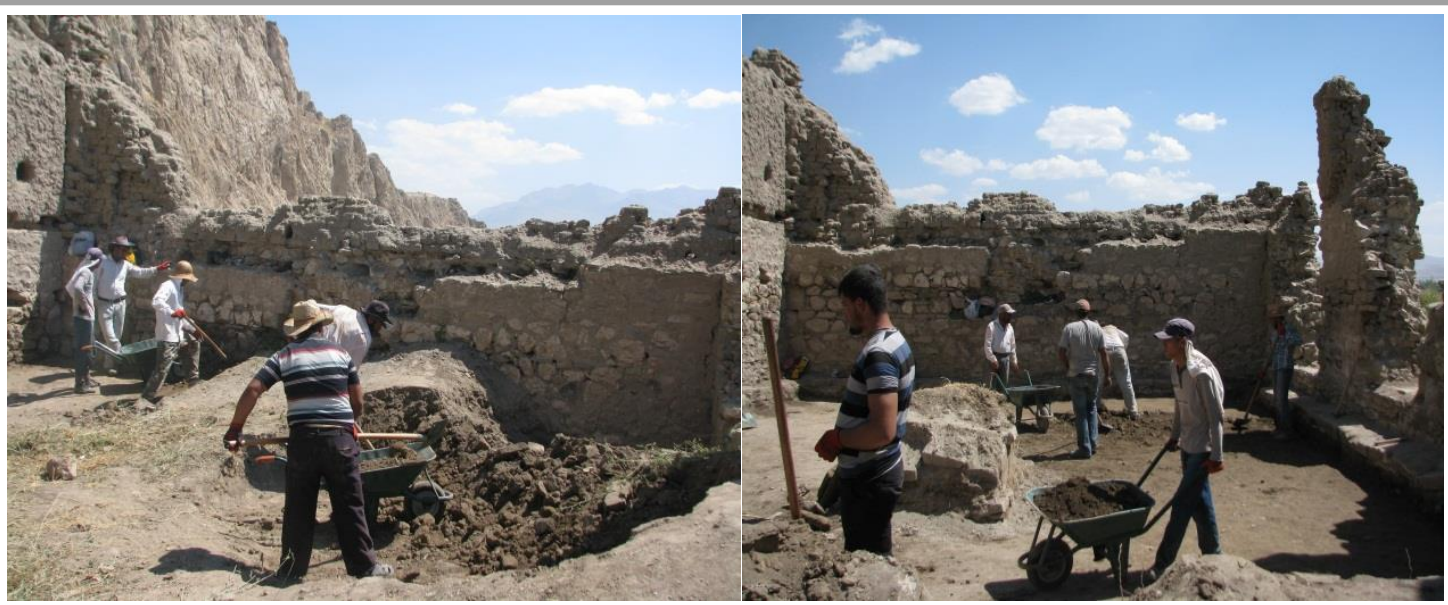

Şekil 5. ve Şekil 6. İç Mekân Kazı ve Temizlik Çalışma Görünüşü (Ş. Öztürk)

Yapılan kazı ve temizlik çalışmalarında yapının iç mekân zemin kot seviyesi, kemer ayakları, ahşap mahfil ayakları, zemin kaplaması, minber, mihrap, oturma sekileri kapı- pencere söveleri tespit edilmiştir.

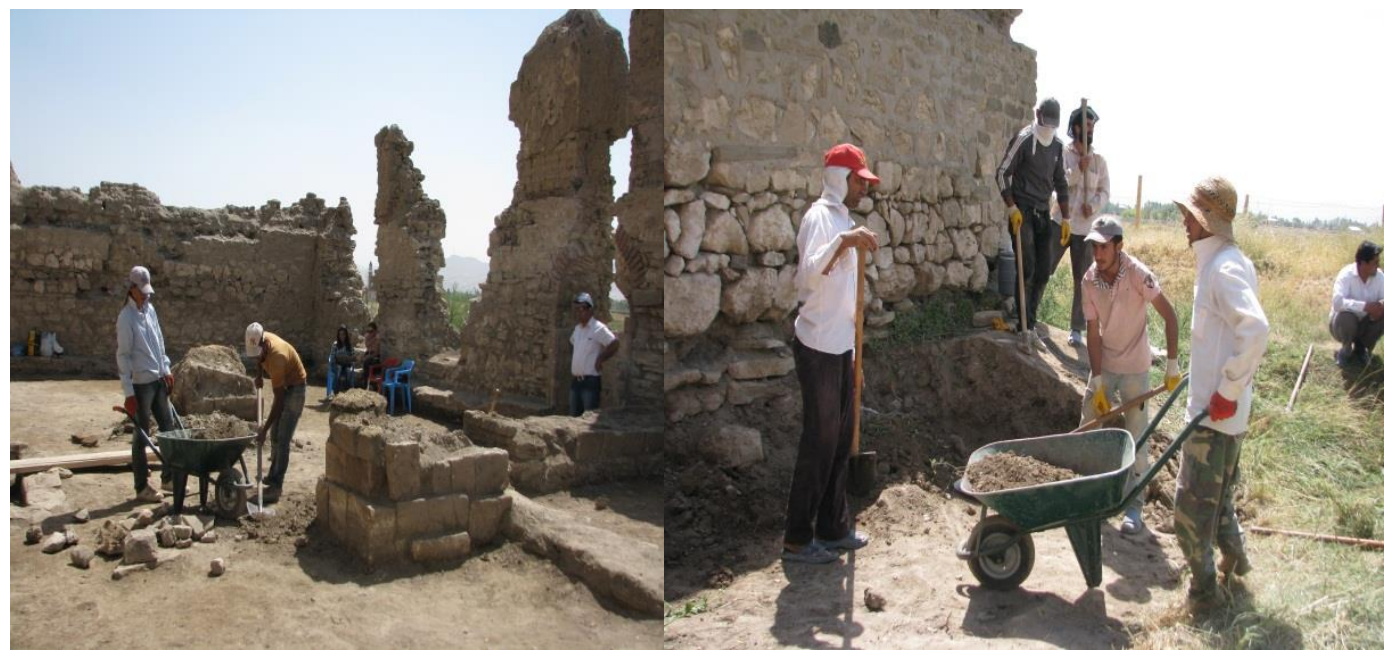

Şekil 7. ve Şekil 8. İç Mekân ve Avlu Kazı ve Temizlik Çalışma Görünüşü (Ş. Öztürk)

Yapının dışında yapılan kazı ve temizlik çalışmalarında ise, güney yol kod seviyesi ve mimarı kaplama dokusu, kuzey giriş bölümünde yer alan dibek taşları, su kuyusu, avlu zemin kot seviyesi ve diğer birçok mimari elemanları yeri ve mimari özellikleri tespit edilerek kayıt altına alınmıştır (Şekil 5-8).

Kazı ve temizlik çalışmaları esnasında hafriyat içerisindeki birçok çanak-çömlek, çiniseramik, metal elemanlar, ahşap amorf parçaları ayrı ayrı tasnif edilmiştir. Ayrıca, mimari yapı malzemesi olan tuğla, kerpiç ve yonu taş malzemeleri envanteri yapılarak kayıt altına alınmıştır (Şekil 9-28). Kazı ve temizlik çalışmalarından sonra yapının rölöve, restitüsyon ve restorasyon projeleri yeniden hazırlanmıştır. 

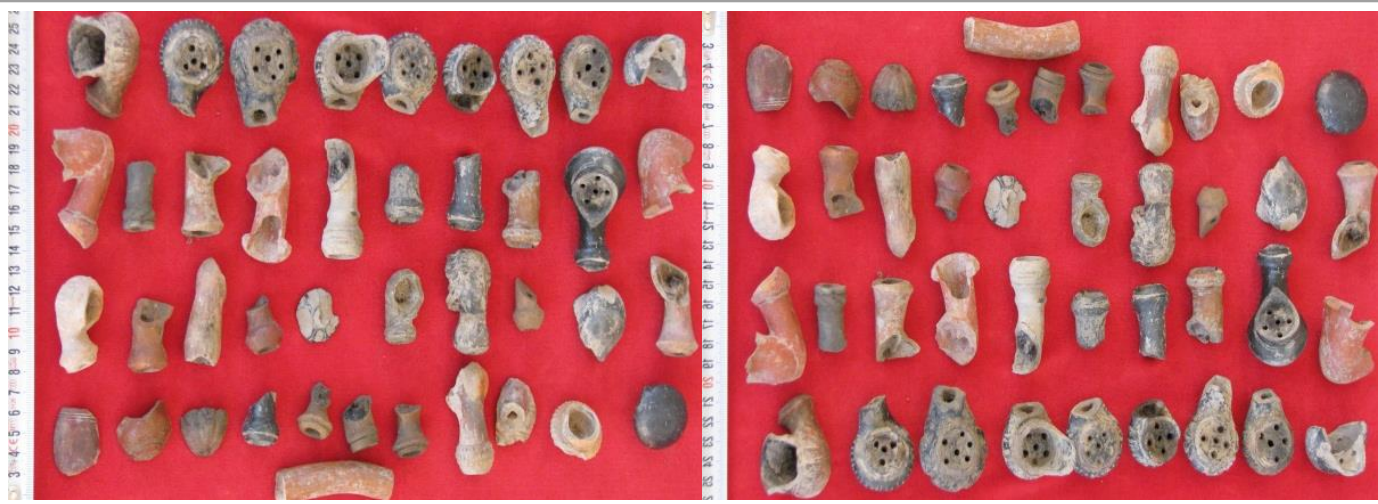

Şekil 9. ve Şekil 10. Kazı Çalışmalarında Tespit Edilen Pipo Görünüşleri (Ş. Öztürk)

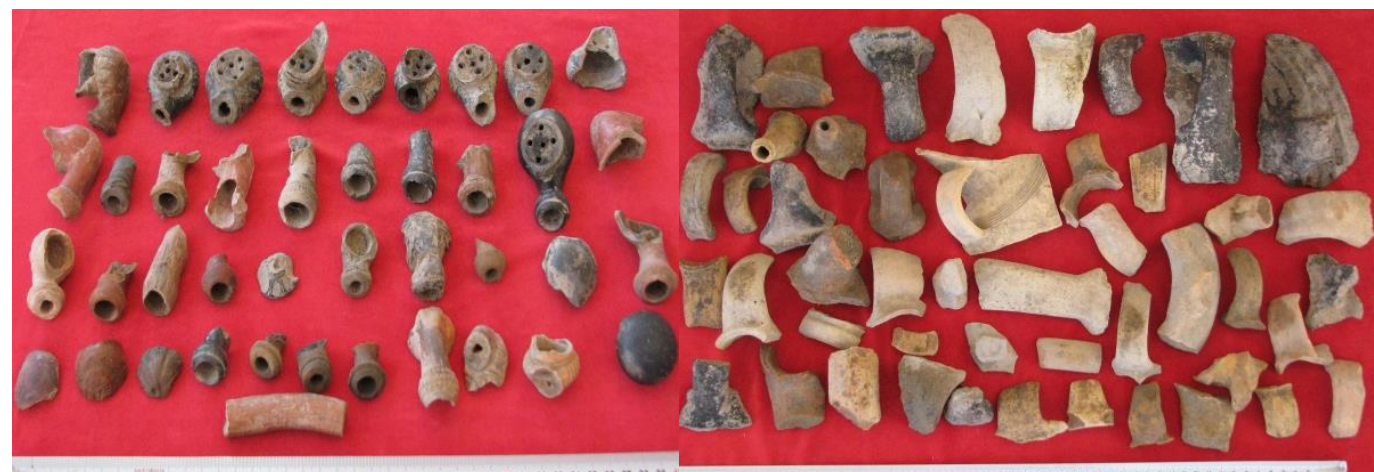

Şekil 11. ve Şekil 12. Kazı Çalışmalarında Tespit Edilen Pipo Görünüşleri (Ş. Öztürk)

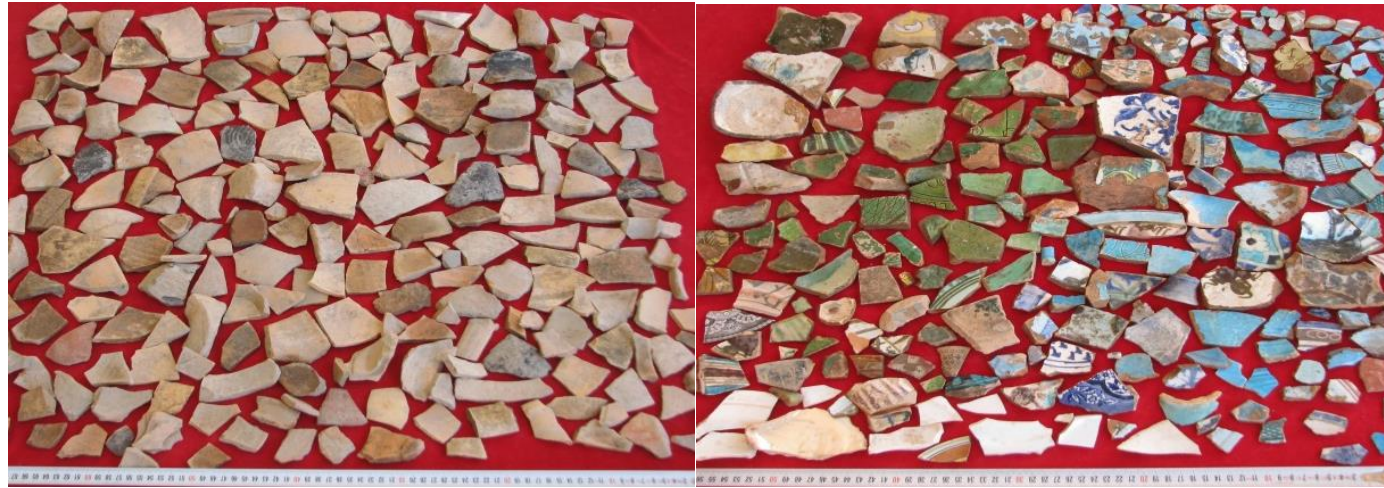

Şekil 13. ve Şekil 14. Kazı Çalışmalarında Tespit Edilen Seramik ve Çanak Görünüşleri (Ş. Öztürk)

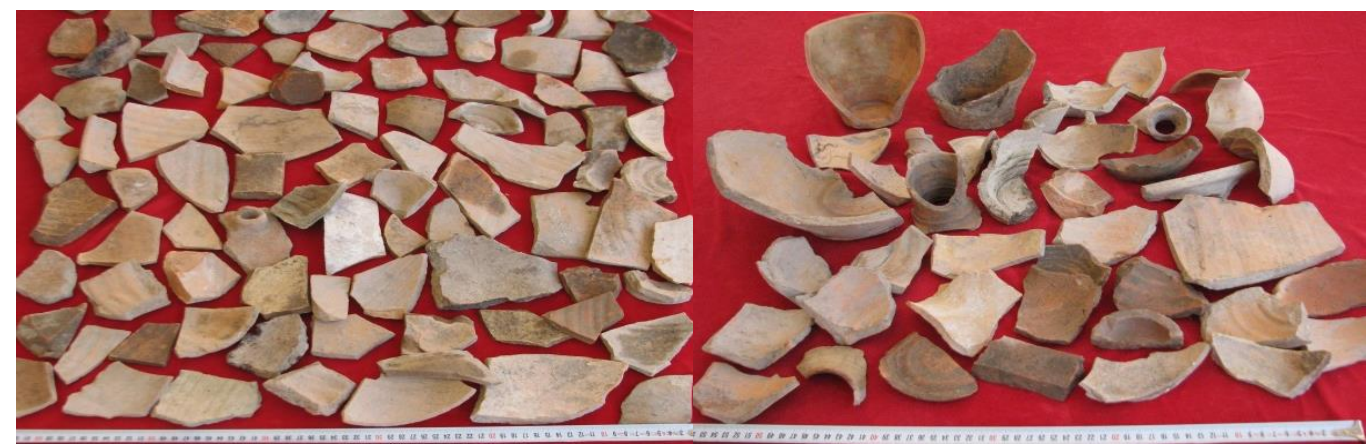

Şekil 15. ve Şekil 16. Kazı Çalışmalarında Tespit Edilen Seramik ve Çanak Görünüşleri (Ş. Öztürk) 


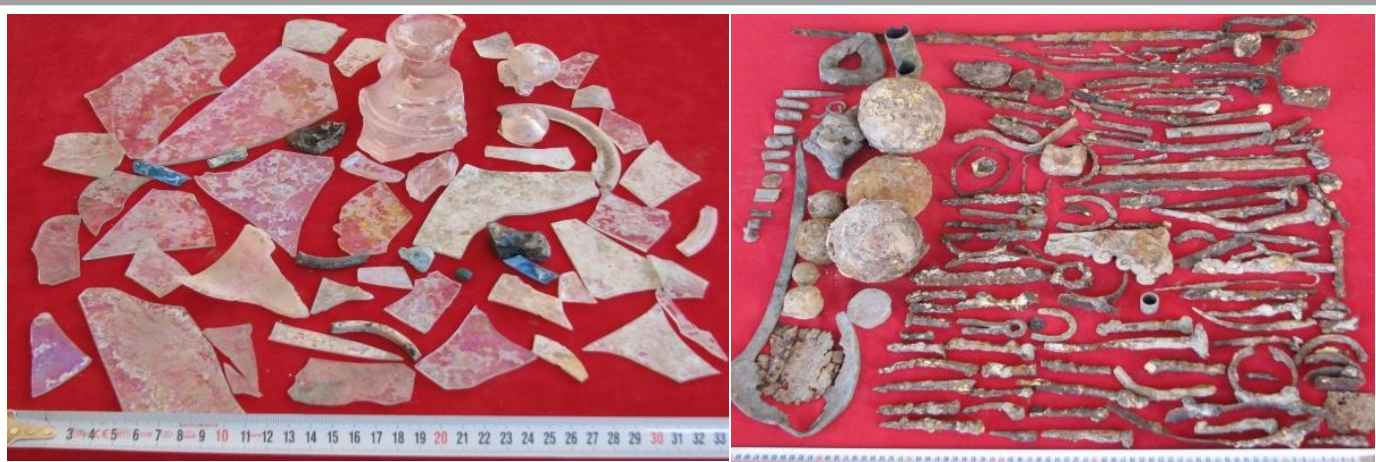

Şekil 17. ve Şekil 18. Kazı Çalışmalarında Tespit Edilen Cam ve Metal Görünüşleri (Ş. Öztürk)

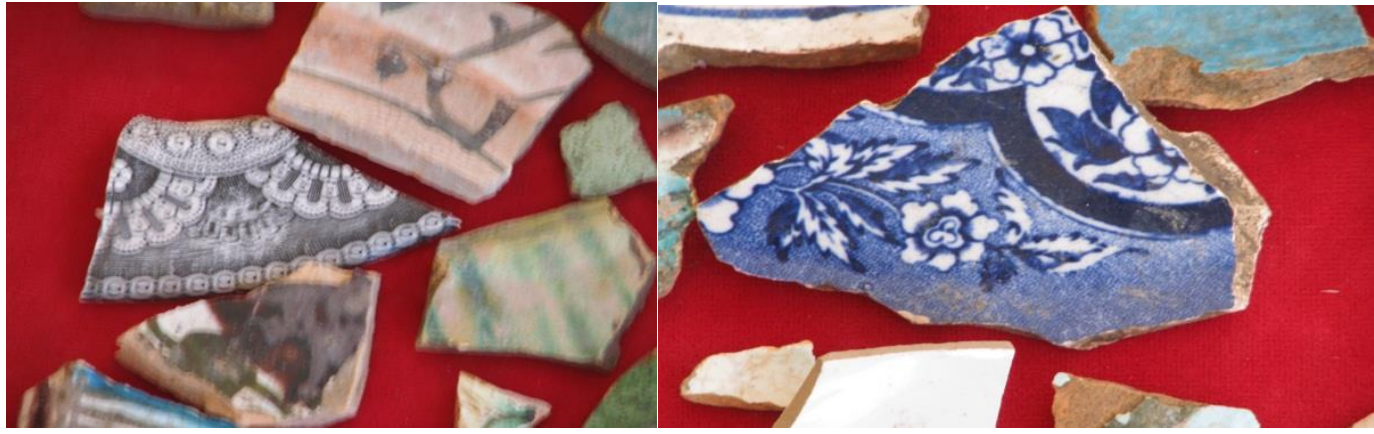

Şekil 19. ve Şekil 20. Kazı Çalışmalarında Tespit Edilen Seramik Parça Görünüşleri (Ş. Öztürk)

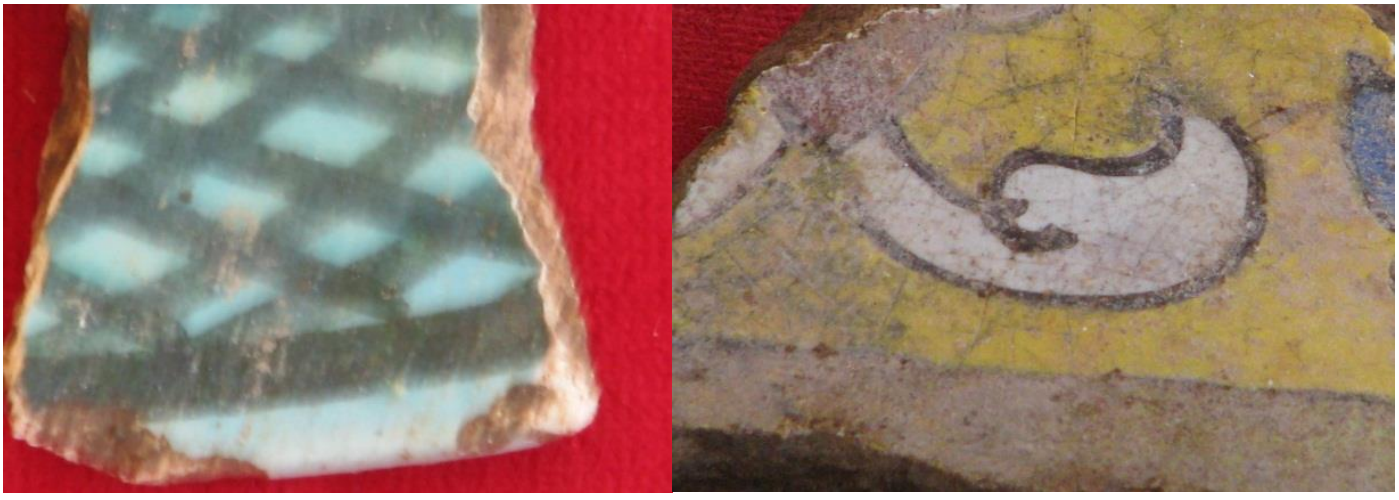

Şekil 21. ve Şekil 22. Kazı Çalışmalarında Tespit Edilen Seramik Parça Görünüşleri (Ş. Öztürk)

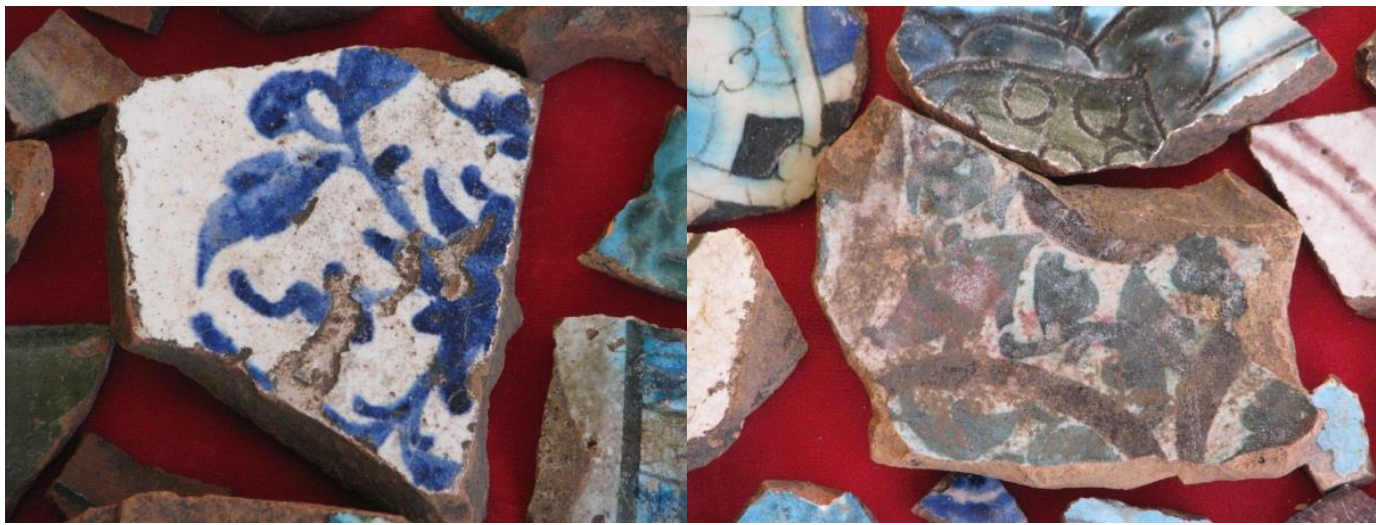

Şekil 23. ve Şekil 24. Kazı Çalışmalarında Tespit Edilen Seramik Parça Görünüşleri (Ş. Öztürk) 


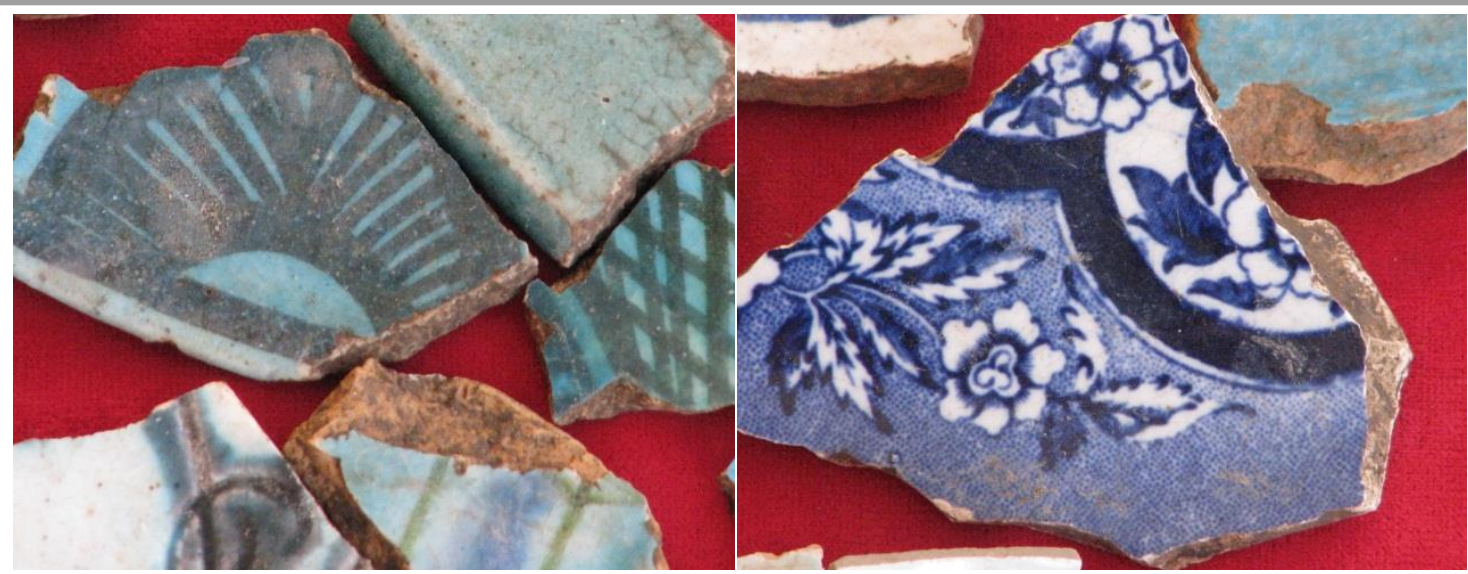

Şekil 25. ve Şekil 26. Kazı Çalışmalarında Tespit Edilen Seramik Parça Görünüşleri (Ş. Öztürk)

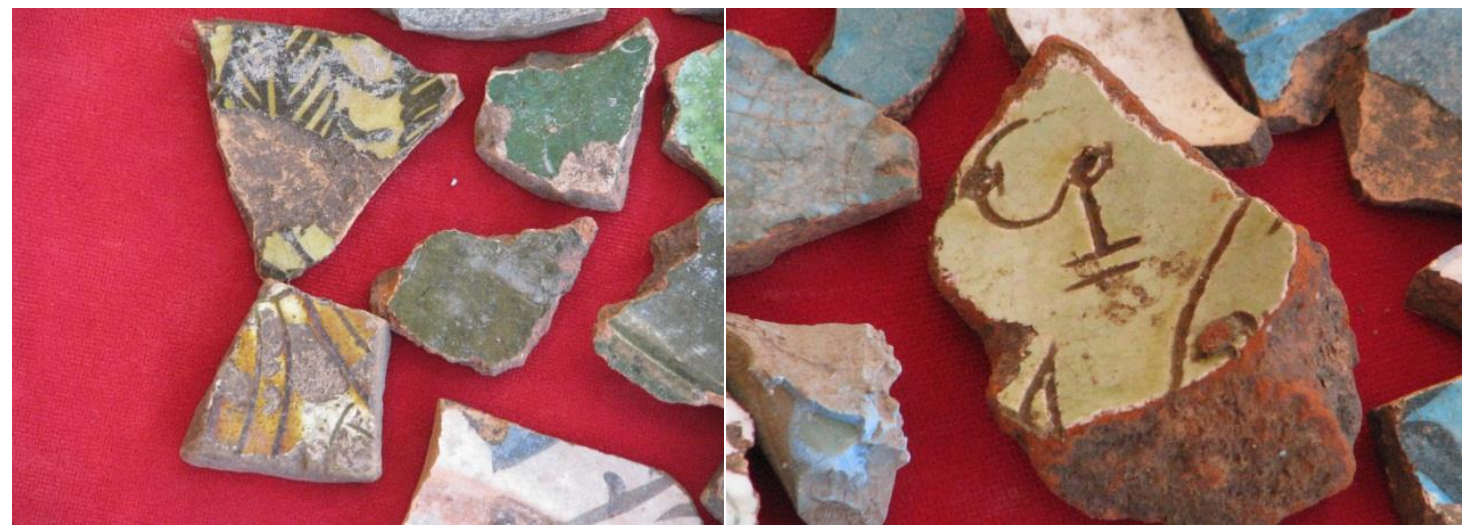

Şekil 27. ve Şekil 28. Kazı Çalışmalarında Tespit Edilen Seramik Parça Görünüşleri (Ş. Öztürk)

\section{Yapının İncelenmesi}

\subsection{Plan}

Abbas Ağa Camii'ne kuzey beden duvarının ortasındaki sivri bir kemer nişi içerisinde yer alan 1.40 m. genişlikteki çift kanatlı ahşap kapı yardımıyla iç mekâna giriş sağlanır. Giriş kapısı iç platformu (Ayakkabılık Bölümü) 1.86x2.22 m. ölçülerinde $0.12 \mathrm{~m}$. iç zemin kotundan daha düşük inşa edilmiştir.

İç mekân, 9.23x18.69 m. ölçülerinde dikdörtgen planlı doğu-batı istikametinde gelişen plandan oluşmuştur. Giriş kapısı aksı üzerinde güney beden duvarının ortasında yer alan mihrap nişi 0.64. derinlikte, $1.12 \mathrm{~m}$. Genişlikte, yuvarlak planlı, köşelerdeki sutünceler ile yuvarlak bir kemer ile yonu kalker taşı kullanılarak şekillenmiştir. Mihrap nişi dıştan bir sıra tuğladan yuvarlak kemer ile çevrelenmiştir. Mihrabın batısında yer alan minber platformu zemin kotundan üç basamak $(0.68 \mathrm{~m}$. $)$ yüksek inşa edilmiştir (Şekil 29).

Caminin ortasında yer alan iki adet benzer mimari özellikteki 1.10x1.10 m. ölçülerindeki kare yonu taşından inşa edilmiş ayaklar, kaideler üzerine yerleştirilen üç adet sivri kemer yardımıyla cami doğu-batı yönünde gelişen iki bölüme ayrılmıştır. Caminin güney, doğu, batı ve kuzey beden duvarları boyunca $0.45 \mathrm{~m}$. yükseklikte, $0.48 \mathrm{~m}$. genişlikte kalker yonu taştan oturma sekileri devam eder (Şekil 29-32). 


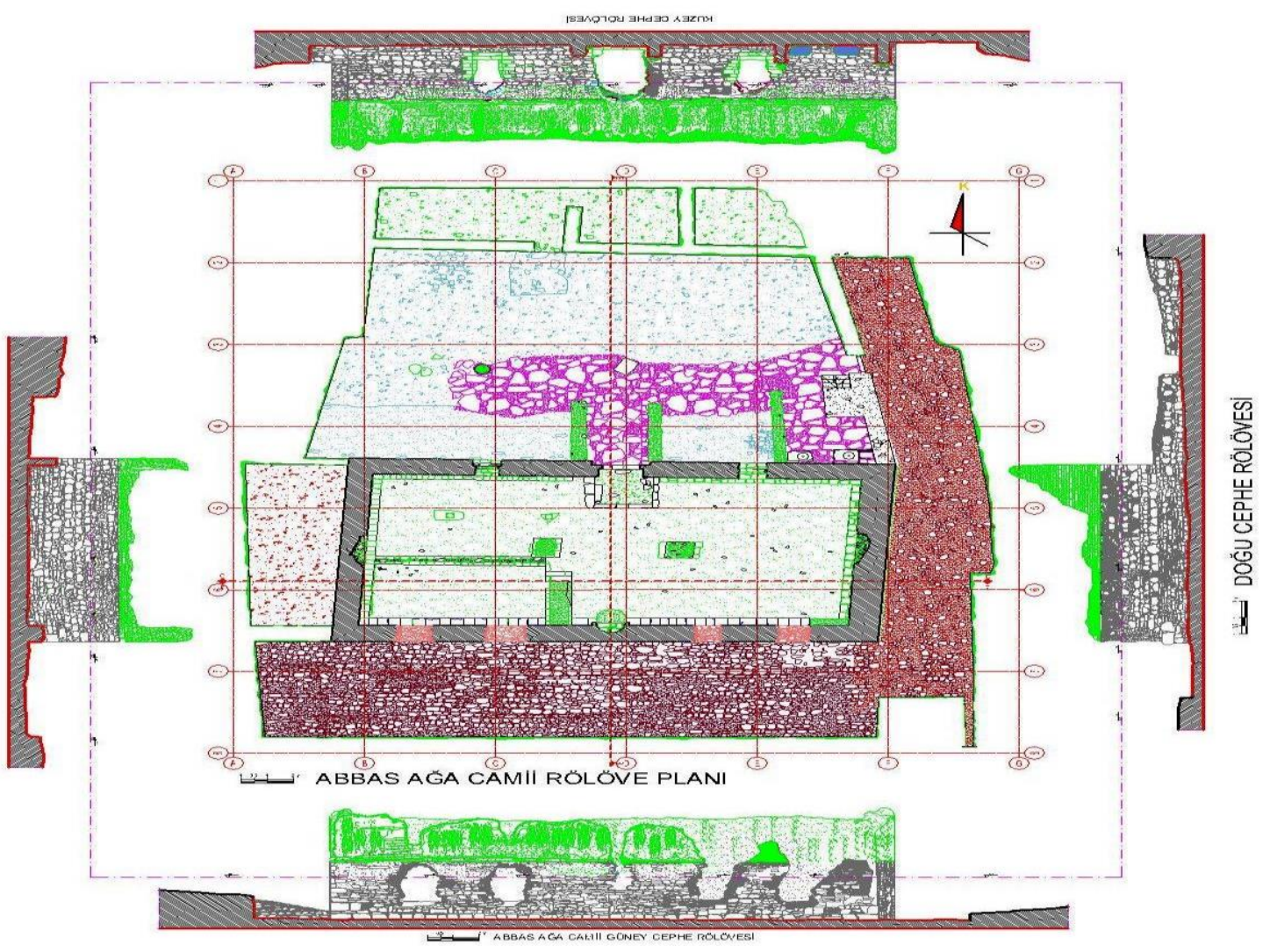

Şekil 29. Abbas Ağa Camii Rölöve Vaziyet Planı (Ş. Öztürk)

Yapının güney beden duvarında dört, kuzey beden duvarı üzerinde yer alan iki olmak üzere, toplam altı adet benzer mimari özelliklerde yonu taşta inşa edilmiş $0.80 \mathrm{~m}$. genişlikte dikdörtgen formunda pencereler bulunur. Mahfil kotunda ise güney beden duvarında beş, doğu ve batı beden duvarlarında ise karşılıklı ikişer olmak üzere, toplam dokuz adet $0.60 \mathrm{~m}$. genişlikte benzer mimari özelliklerde kuşkanat mazgal pencere yer alır.

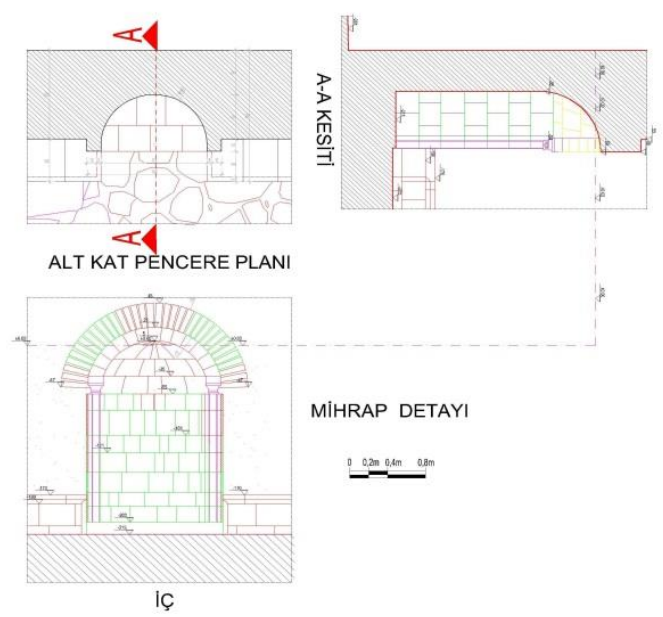

Şekil 30. ve Şekil 31. Abbas Ağa Camii Mihrap Rölöve ve Restorasyonu (Ş. Öztürk) 
Giriş kapısının doğusunda kuzey beden duvarına bitişik ve paralel olarak inşa edilen $1.00 \mathrm{~m}$. genişliğindeki tek kollu ahşap bir merdiven ile ahşaptan imal edilmiş mahfil katına çıkış sağlanır (Şekil 29). Ahşaptan inşa edilen $2.70 \mathrm{~m}$. Genişlikteki mahfil katı, kuzey beden duvarı boyunca devam eder. Mahfil katı zemindeki dört adet dekoratif taş kaide üzerindeki ahşap dikmeler yardımıyla desteklenmiştir.

Caminin iç mekânındaki sesi düzenlemek amacıyla kuzey ve güney beden duvarlarında yedişer, doğu ve batı beden duvarlarında ise dört olmak üzere, toplam 22 adet aks-i seda küpleri beden duvarlar içerisine yerleştirilmiştir (Şekil 33-36).

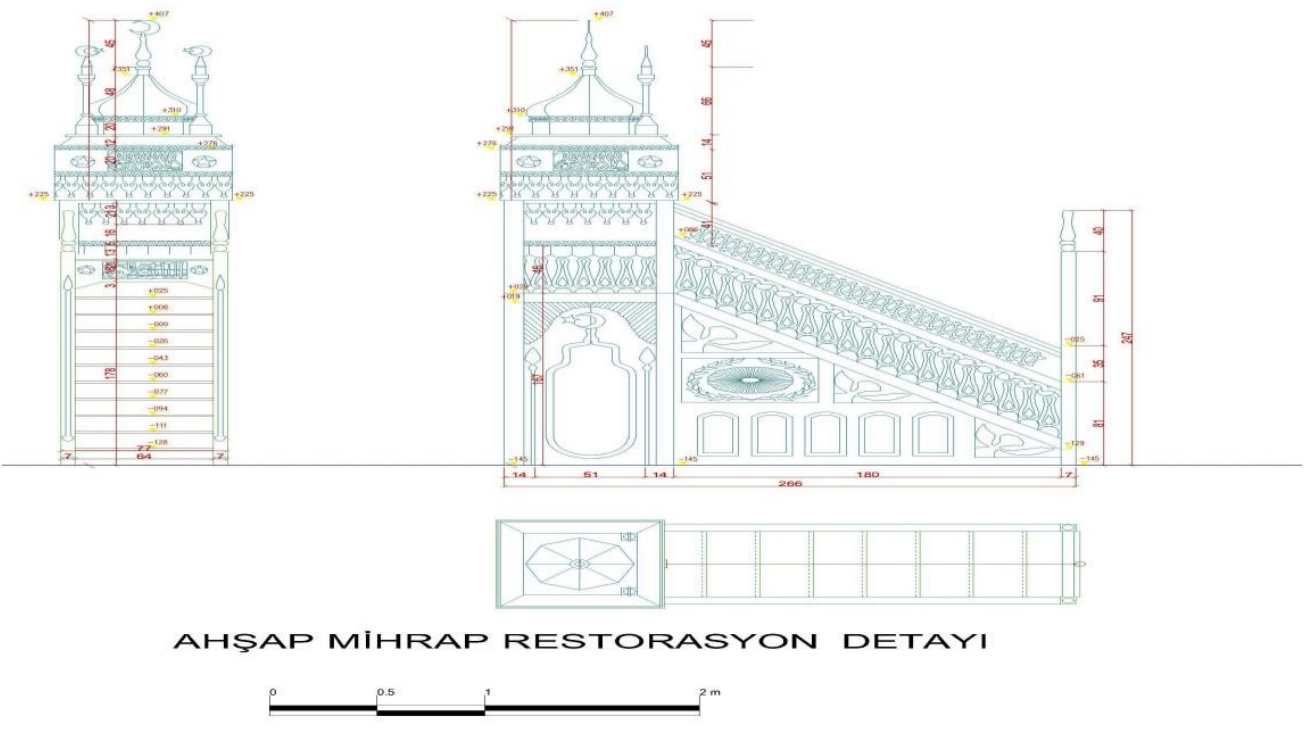

Şekil 32. Abbas Ağa Camii Ahşap Minber Restorasyonu (Ş. Öztürk)

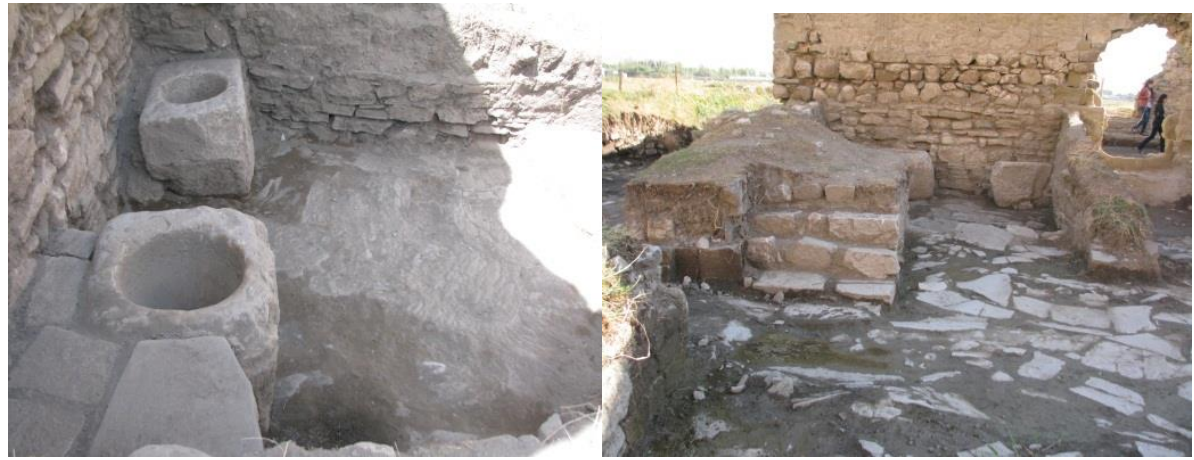

Şekil 33 ve Şekil 34. Kazı Çalışmalarında Tespit Edilen Dibek Taşı Görünüşleri (Ş. Öztürk) 


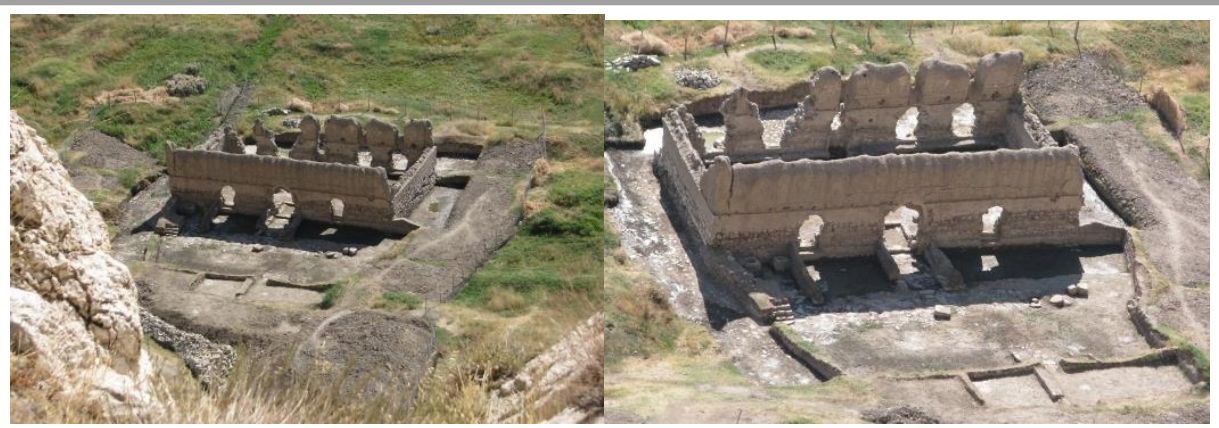

Şekil 35 ve Şekil 36. Kazı Sonucu Ortaya Çıkarılan Cami Genel Görünüşleri (Ş. Öztürk)

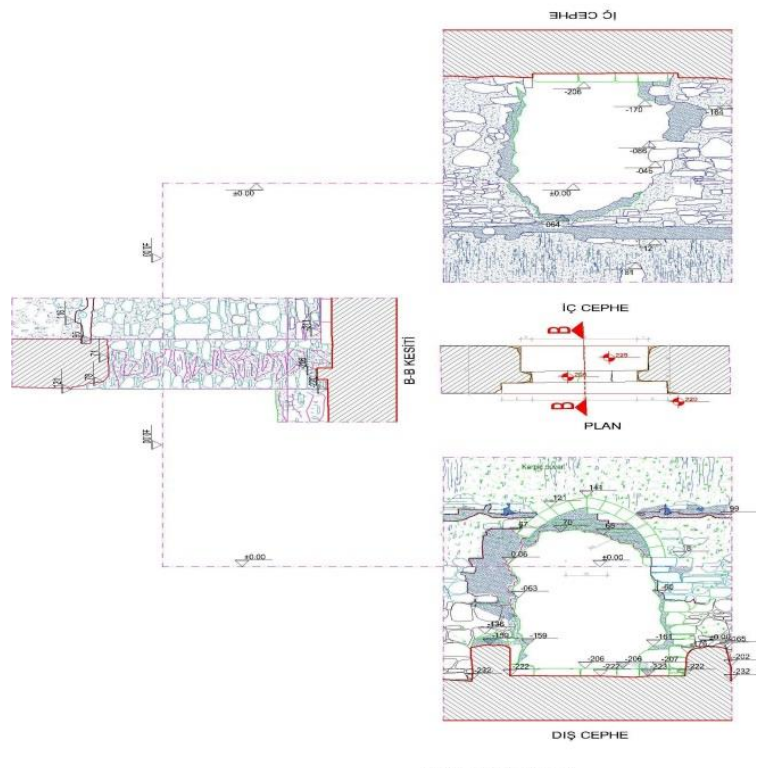

KAPI ROLOVE DETAYI
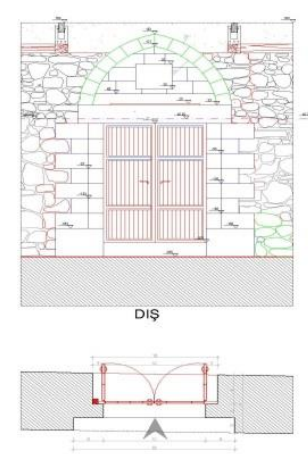

KAPIPLANI

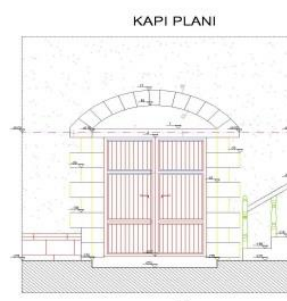

Şekil 37 ve Şekil 38. Abbas Ağa Camii Kapı Rölöve ve Restorasyonu (Ş. Öztürk)
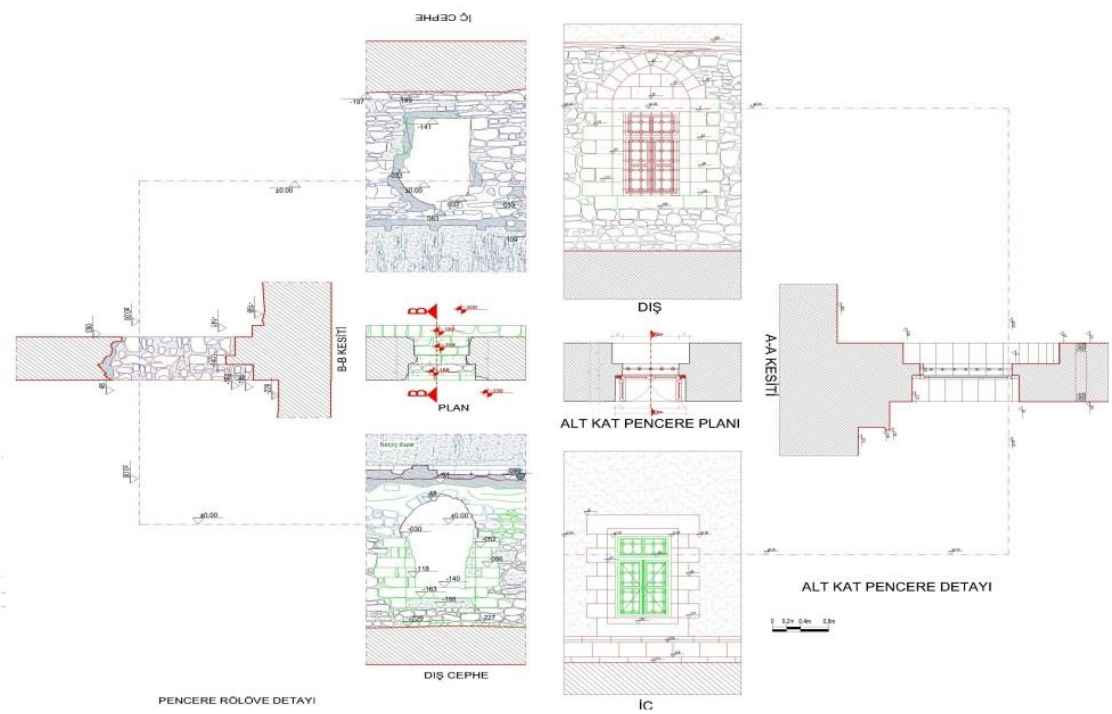

Şekil 39 ve Şekil 40. Abbas Ağa Camii Pencere Rölöve ve Restorasyonu (Ş. Öztürk) 


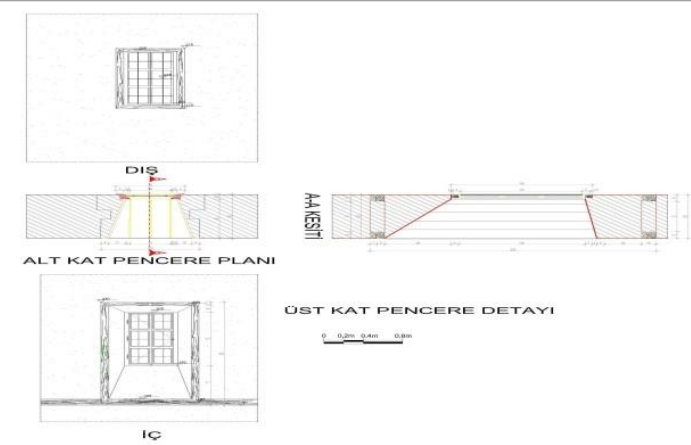

Şekil 41. Abbas Ağa Camii Üst Pencere Restorasyonu (Ş. Öztürk)

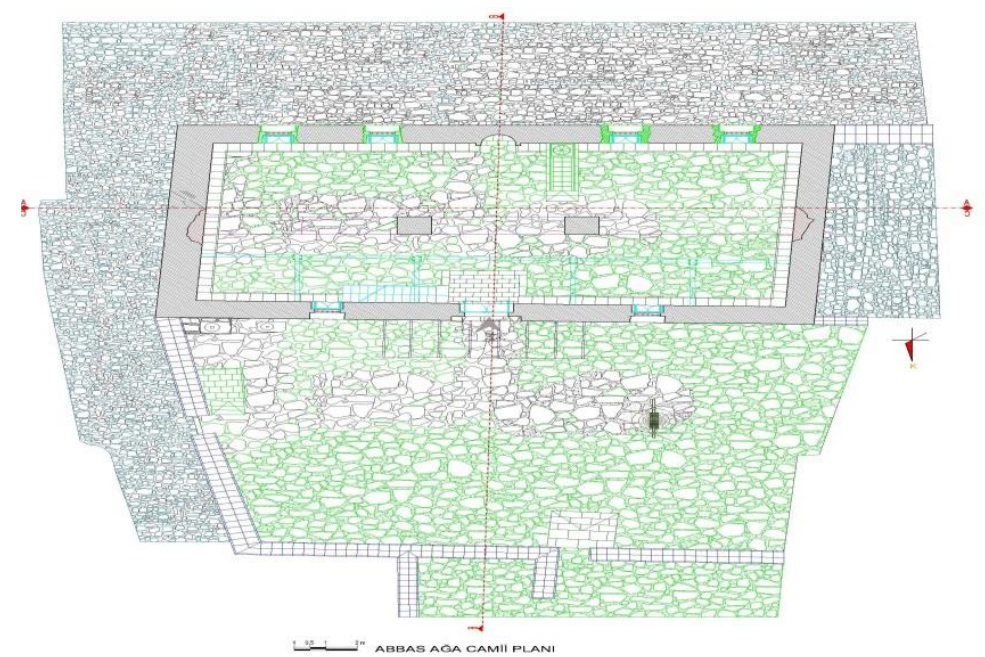

Şekil 42. Abbas Ağa Camii Restorasyon Planı (Ş. Öztürk)

Yapıyı oluşturan beden duvarlarından güney ve kuzey duvar $1.00 \mathrm{~m}$. doğu duvarı $1.20 \mathrm{~m}$., batı duvarlarının kalınlığ 1 ise 0.95 m'dir. Yapının tüm beden duvarları zeminden itibaren $3.70 \mathrm{~m}$. moloz taş duvar ile yükselerek $0.15 \mathrm{~m}$. ahşap hatıl ile iç ve dıştan çevrelendikten sonra, beden duvarlar kerpiç olarak devam edilerek düz toprak dama geçiş sağlanır.

Yapının iç bölümündeki üç adet yonu taştan inşa edilmiş kemerlerin satıhları sıvasız, diğer beden duvarları iç kısmı ise saman, odun külü ve kaya tuz katkılı çamur sıva ile sıvalıdır (Şekil 37-50). 


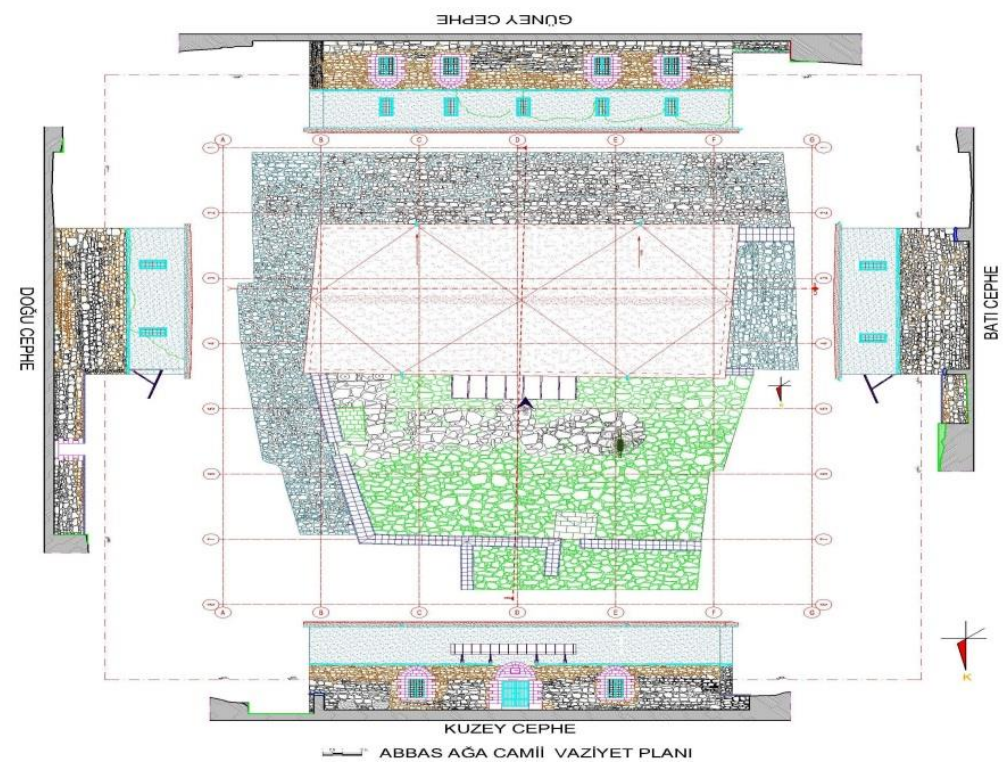

Şekil 43. Abbas Ağa Camii Restorasyon Vaziyet Planı (Ş. Öztürk)

Abbasağa Camii’nin doğu ve güneyinde yer alan sokaklar moloz taş kaplamalıdır. Güney yolu düzenli olarak devam ederek $5.78 \mathrm{~m}$. genişliktedir. Yapının doğusunda yer alan sokak yol düzensiz bir yapıda olup, yol genişliği yer yer değişmektedir. Yapının batısındaki beden duvarı daha alt kotta devam ederek iki duvar arasındaki zemin moloz taş kaplamalı olarak düzenlemiştir.

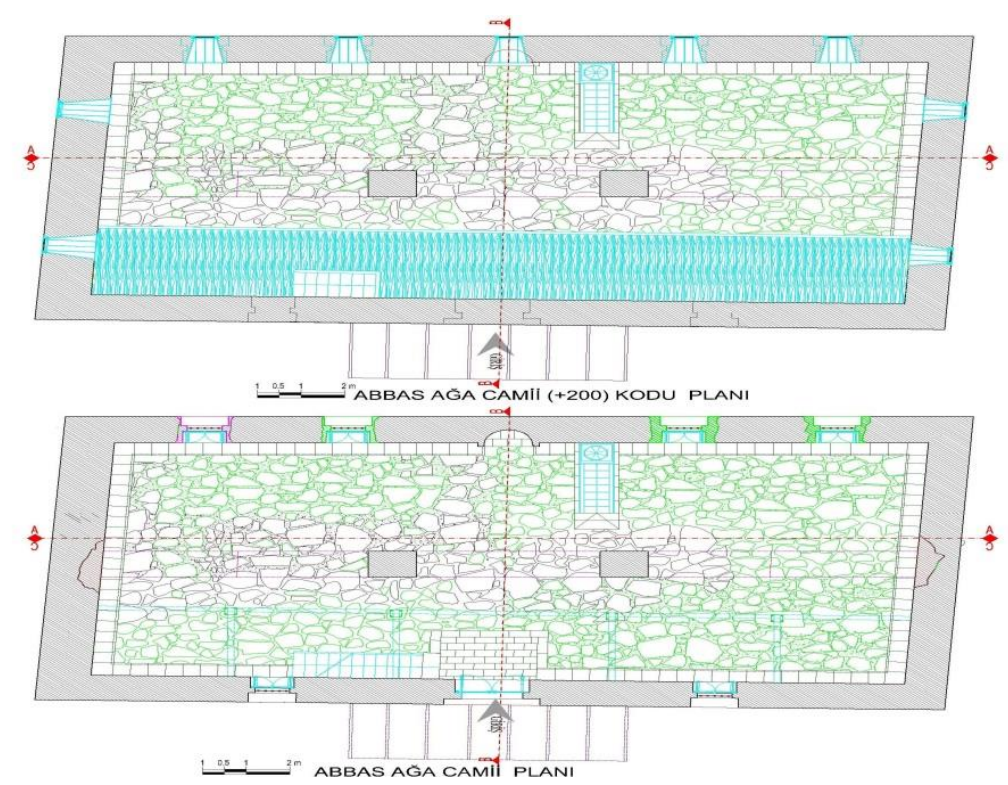

Şekil 44 ve Şekil 45. Abbas Ağa Camii Zemin ve Mahfil Kat Restorasyon Planı (Ş. Öztürk) 


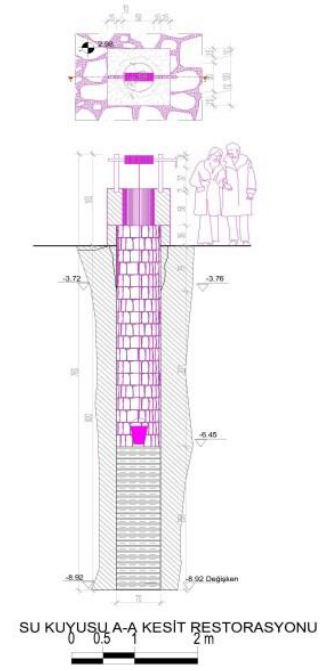

Şekil 46. Abbas Ağa Camii Su Kuyusu Restorasyonu (Ş. Öztürk)

Kayrak taş kaplamalı cami avlusuna giriş doğudan $1.00 \mathrm{~m}$. genişlikteki kapı ile sağlanır. Yapının kuzeyinde yer alan avlu oldukça geniş $16.54 \times 19.92 \mathrm{~m}$. ölçülerinde ve iki kademeli olarak planlanmıștır. Avlu giriș kapısının hemen güneyinde yer alan platform 1.51x1.87 m. ölçülerinde, avlu zemin kotundan yaklaşı $0.89 \mathrm{~m}$. yüksekliğindedir. $\mathrm{Bu}$ platform hayvanlarla getirilen buğday çuvallarının konulduğu yer olarak kullanılmaktadır. Avlunun güneydoğu köşesinde iki adet yekpare kalker taşından inşa edilmiş dibek taşı yer almaktadır (Şekil 33).

Avlunun batı bölümüne yakın bir alanda kesme taştan inşa edilmiş bir su kuyusu mevcuttur. Su kuyusu abdest almak, çevre temizliği ve taban suyunu regule etmek amaciyla inşa edilmiştir. Avlunun kuzeyindeki kot farkı üç adet merdiven basamağı ile aşılarak üst kota çıkış sağlanır. Avlunun doğu ve kuzey çevre duvarları $0.80 \mathrm{~m}$. genişlikte yonu taşından imal edilmiş harpuşta ile koruma altına alınmıştır (Şekil 43).

\subsection{Cepheler}

Kuzey cephesi, $6,75 \mathrm{~m}$. yüksekliğinde $20.93 \mathrm{~m}$. uzunluğundadır. Yapının tüm cepheleri zemin kotundan $3.40 \mathrm{~m}$. yükselen moloz yapılı beden duvarı $0.15 \mathrm{~m}$. genişlikteki ahşap hatıl ile çevrelenmiş, duvarlar $2.81 \mathrm{~m}$. kerpiç yapılı beden duvar yükselerek $0.30 \mathrm{~m}$. dışa ahşap taşıntılı düz saçak yardımıyla toprak düz dama geçiş sağlanmıştır. 


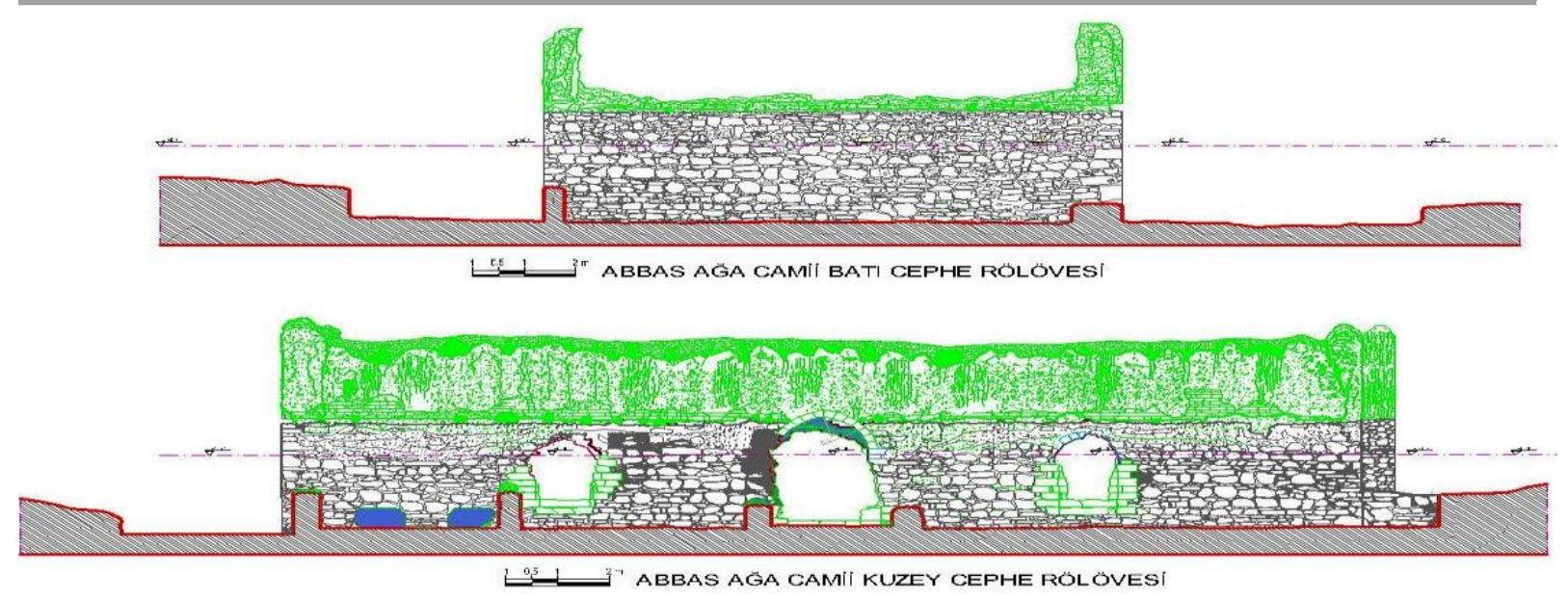

Şekil 47 ve Şekil 48. Abbas Ağa Camii Kuzey ve Batı Cephe Rölövesi (Ş. Öztürk)

Kuzey cephesinin ortasında yer alan çift kanatlı ahşap giriş kapısı sivri bir kemer içerisinde biçimlenmiştir. Giriş kapısının üzerine kar ve yağmur sularından korunmak amacıyla dört adet ahşap payanda ile desteklenmiş kurşun kaplamalı markiz yerleştirilmiştir (Şekil 48).

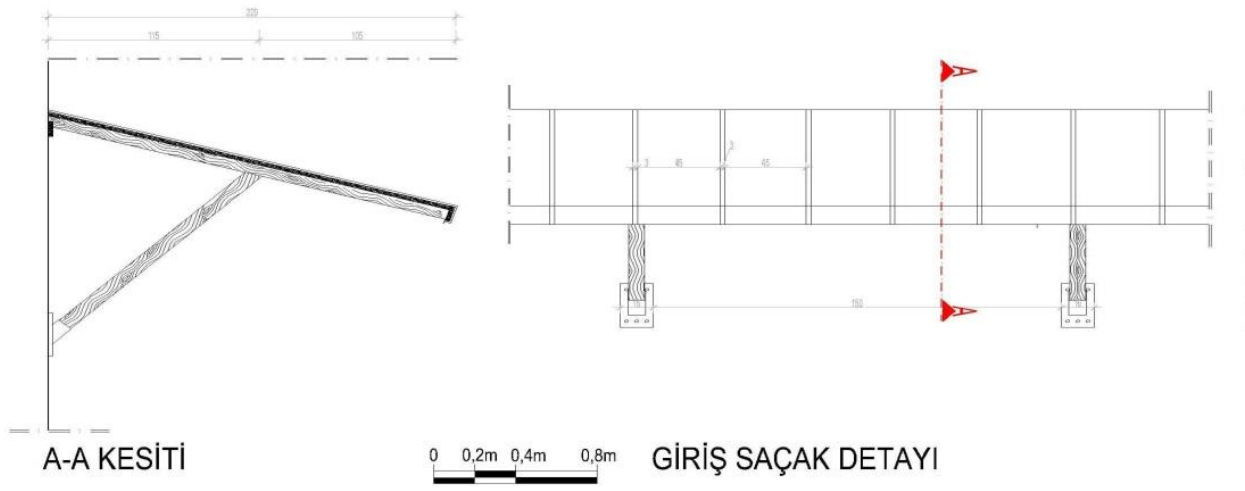

Şekil 49. Abbas Ağa Camii Giriş Markiz Restorasyonu (Ş. Öztürk)

Giriş kapısının her iki yanında simetrik olarak sivri kemer içerisine yerleştirilmiş iki pencere yer almaktadır. Ayrıca, cephede iki adet ahşaptan imal edilmiş çörten (Şöratan) yer almaktadır (Şekil 44,45). Güney cephesi, $7.02 \mathrm{~m}$. yüksekliğinde $20.85 \mathrm{~m}$. uzunluğundadır. Güney cephesinin alt ve üst kısmındaki toplam dokuz pencere yatay ve düşeyde aynı aks üzerinde yer alarak cepheye hareketlilik sağlamıştır. Alt bölümdeki pencerelerin üzeri sivri bir kemer ile şekillenmiştir. Üst kat pencereleri ise düz atkılı olarak tasarlanmıştır. Ayrıca, cephede iki adet ahşaptan imal edilmiş çörten (Şöratan) yer almaktadir. 


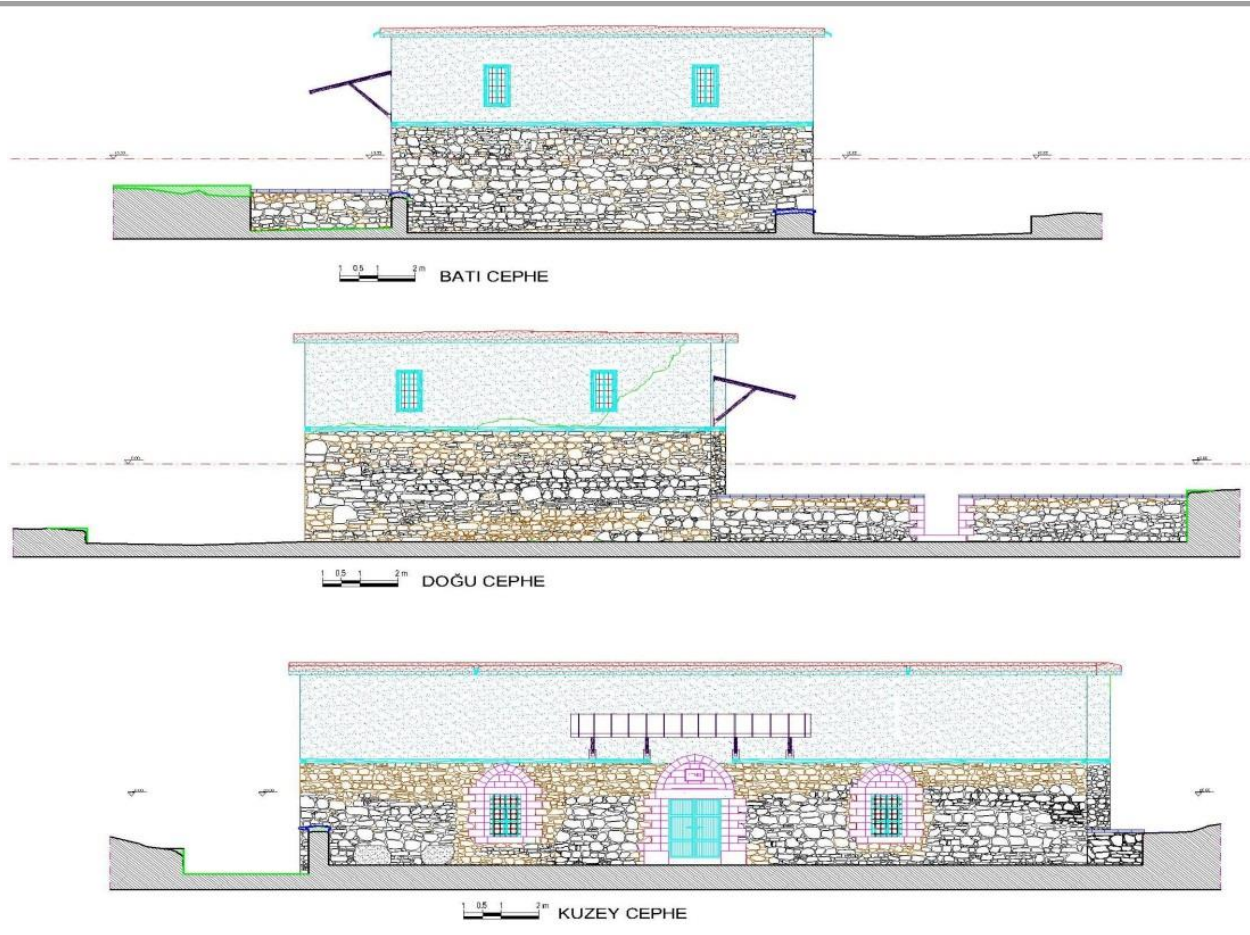

Şekil 50,51 ve Şekil 52. Abbas Ağa Camii Kuzey, Doğu ve Batı Cephe Restorasyonu (Ş. Öztürk)

Doğu cephesi, $7.07 \mathrm{~m}$. yüksekliğinde $10.81 \mathrm{~m}$. uzunluğundadır. Doğu cephesinin üst pencereleri toplam iki adet olup, aynı yatay aks üzerinde yer alarak cepheye bir hareketlilik sağlamıştır. Üst kat pencereleri ise düz atkılı olarak tasarlanmıştır (Şekil 50-54).

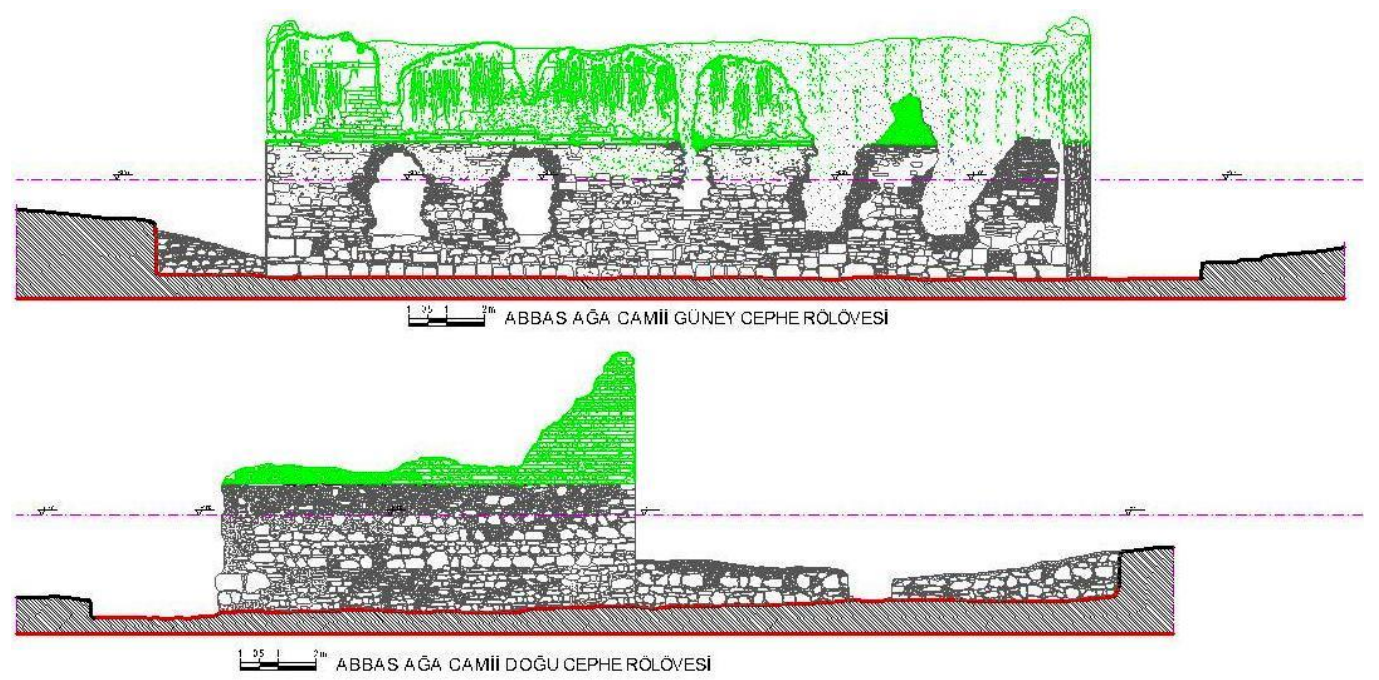

Şekil 53 ve Şekil 54. Abbas Ağa Camii Doğu ve Güney Cephe Rölövesi (Ş. Öztürk)

Batı cephesi, $6.91 \mathrm{~m}$. yüksekliğinde $11.23 \mathrm{~m}$. uzunluğundadır. Batı cephesinin üst iki penceresi yatay aynı aks üzerinde yer alarak cepheye bir hareketlilik sağlamıştır. Üst kat pencereleri ise düz atkılı olarak tasarlanmıştır. 


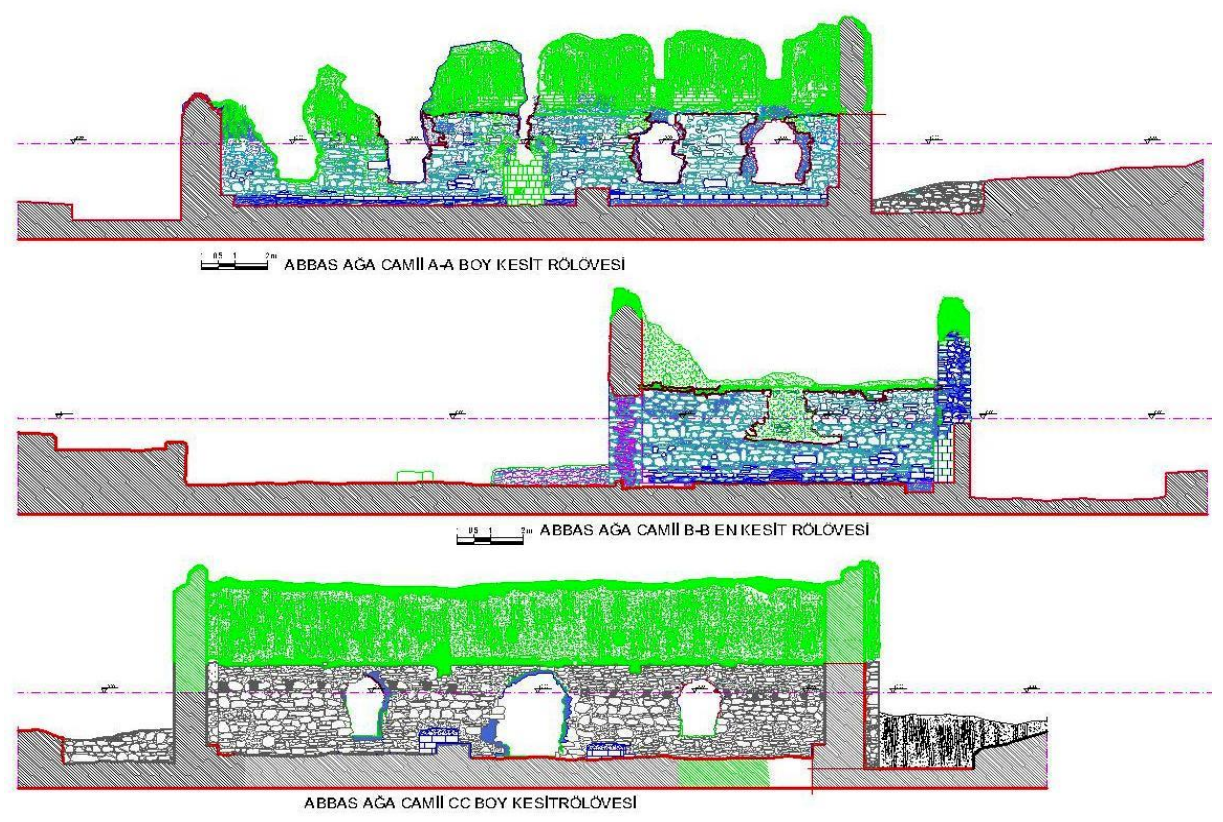

Şekil 55,56 ve Şekil 57. Abbas Ağa Camii A-A,B-B ve C-C Kesit Rölövesi (Ş. Öztürk)
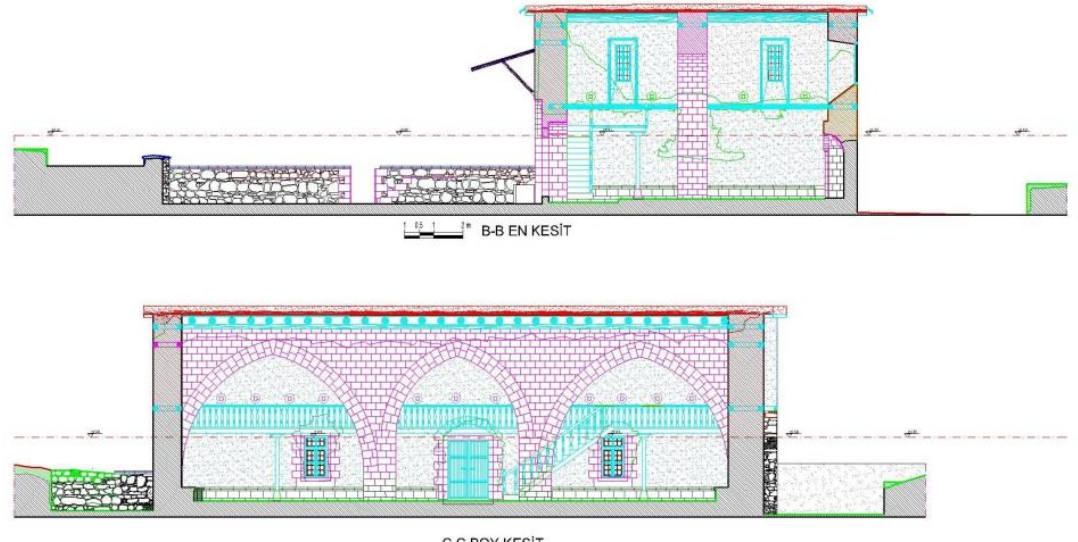

Şekil 58 ve Şekil 59. Abbas Ağa Camii B-B ve C-C Kesit Restorasyonu (Ş. Öztürk)
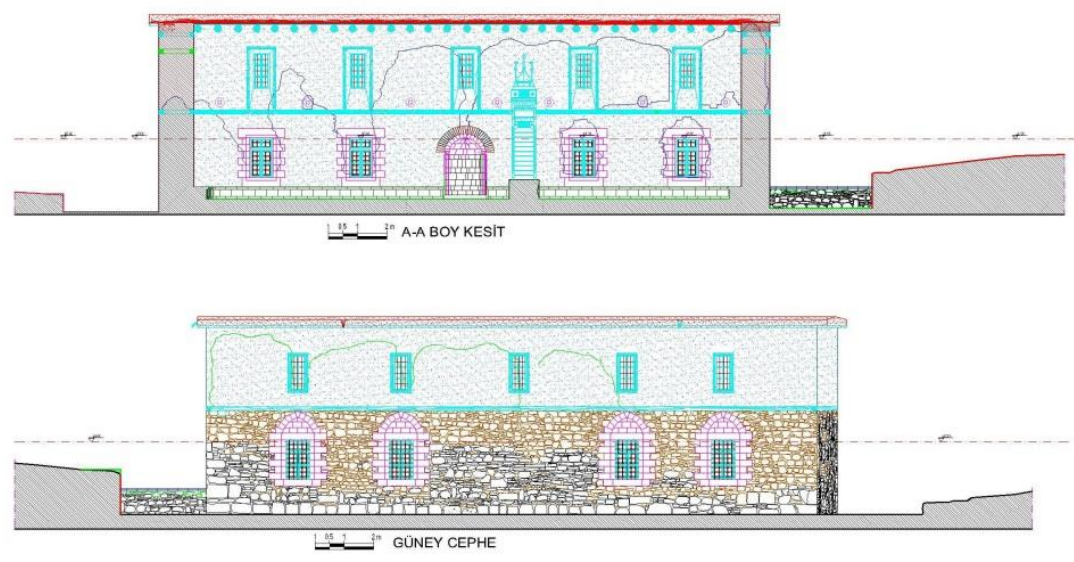

Şekil 60 ve Şekil 61. Abbas Ağa Camii A-A Kesit ve Güney Cephe Restorasyonu (Ş. Öztürk) 


\subsection{Düz Toprak Dam}

Abbasağa Camii'nin düz toprak dam1 11.43x21.45 m. ölçülerindedir. Düz toprak dam kuzey ve güney yönüne doğru \% 4 eğimlidir. Her iki yöne doğru ikişer adet olmak üzere, toplam dört adet çörten yerleştirilerek kar ve yağmur sularının düz toprak damdan tahliyesi sağlanmıştır (Şekil 62).

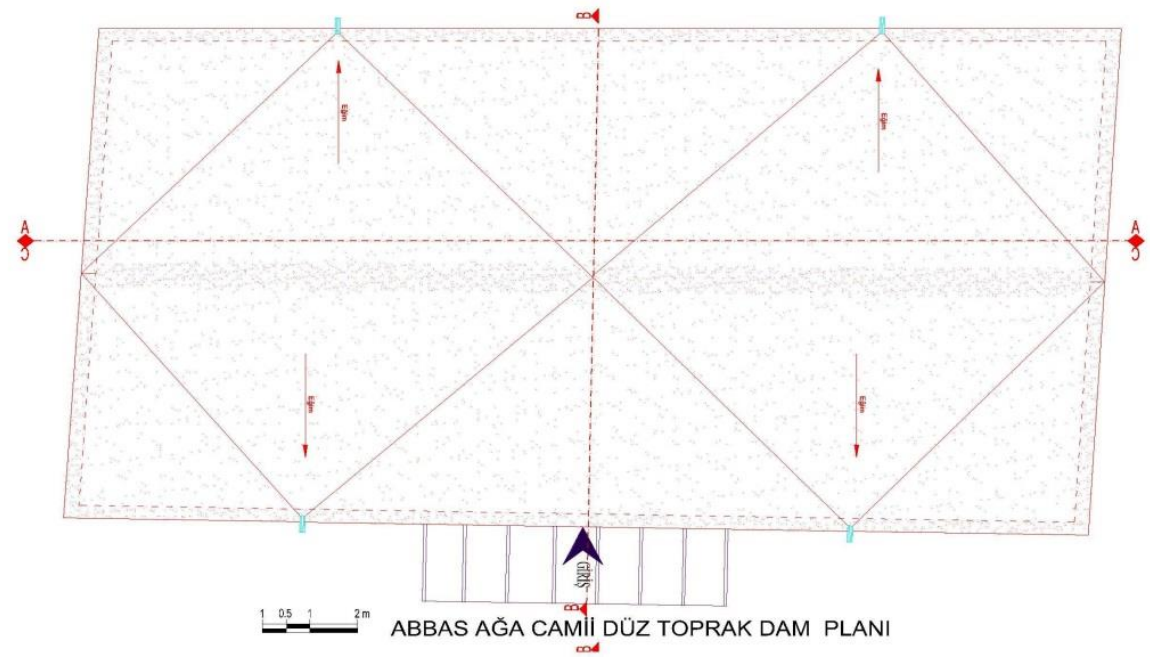

Şekil 62. Abbas Ağa Camii Restorasyon Düz Toprak Dam Planı (Ş. Öztürk)

Kerpiç beden duvarlarının üstü kısmı $0.15 \mathrm{~m}$. kalınlıkta ahşap hatıl ile çevrelenerek, hatıllar üzerine kısa doğrultuda (kuzey-güney) $0.25 \mathrm{~m}$. yuvarlak kesitli ahşap kirişler (keran) yaklaşı $0.40 \mathrm{~m}$. aralıklar ile düzenli olarak yerleştirilir. Ahşap kirişlerin kerpiç beden duvarı içerisindeki uç kısımlar ziftlenerek koruma altına alınır. Ahşap kirişleri üzeri $0.04 \mathrm{~m}$. kalınlıkta ahşap mertek ile kapatılır. Mertek üzeri $0.04 \mathrm{~m}$. kalınlıkta kamış (saz), $0.20 \mathrm{~m}$. kalınlıkta püşürük ve $0.20 \mathrm{~m}$. kalınlıktaki çamur sıva ile tamamlanır (Şekil 62-64).

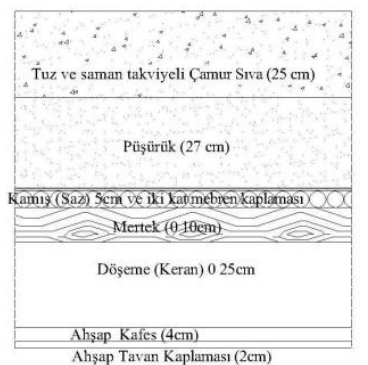

DÜZ DAM DETAYI

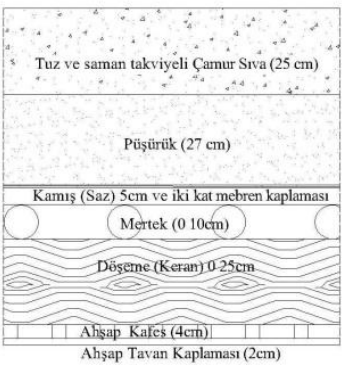

SUTÜN ALTI DETAYI

Şekil 63 ve Şekil 64. Abbas Ağa Camii Düz Dam-Sütun Altı Detayları (Ş. Öztürk)

\section{Malzeme ve Yapım Tekniği}

Abbasağa Camii'nin beden duvarları yığma yapım tekniği ile inşa edilmiştir. Beden duvarlarında üç ayrı yapım tekniği kullanılmış; zeminden yaklaşık $3.40 \mathrm{~m}$. ye kadar moloz yığma dolgu taş tekniğinde daha sonra ise düz toprak dam seviyesine kadar geleneksel kerpiç örgü tekniği ve iç kemerlerde ise sıralı düzgün kesme taş kullanılarak yapı inşa edilmiştir. 
Abbasağa Camii'nin yapımında, moloz taşı, yonu taşı, kayrak sal taşı, kerpiç, tuğla, metal, ahşap ve tuğla kullanılmıştır. Moloz taşı; yapının beden duvarları ve yol zemin kaplamasında, Yonu taşı; cami iç mekân oturma sekilerinde, kapı ve pencere kemer ve sövelerinde, iç kemer yapımında, mihrap yapımında ve avlu harpuşta kaplamasında kullanılmıştır.

Kerpiç; yapılan incelemelerde cami beden duvarlarının üst kesiminde kullanılmıştır. Duvar kalınlıklar; 0.90, 0.96 ve $1.20 \mathrm{~m}$. olup, üç tam, iki tam iki yarım kerpiç kullanılmıştır. Kullanılan tam kerpiç ölçüleri; $(0.8 \times 0.29 \times 0.29),(0.8 \times 0.34 \times 0.34)$ ve $(0.8 \times 0.37 \times 0.37)$

Kullanılan yarım kerpiç ölçüleri; $(0.8 \mathrm{x} 0.10 \mathrm{x} 0.29),(0.8 \mathrm{x} 0.10 \mathrm{x} 0.34)$ ve $(0.8 \mathrm{x} 0.10 \mathrm{x} 0.37)$, (Şekil $65)$
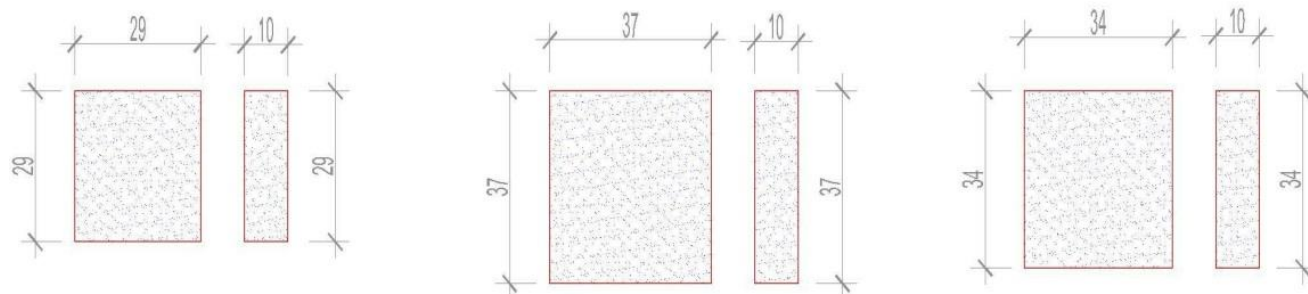

Şekil 65. Abbas Ağa Camii Kullanılan Kerpiç Ölçüleri (Ş. Öztürk)

Ahşap; kapı pencere doğramalarında, beden duvar hatıllarında, merdiven, ahşap mahfil yapımında ve düz toprak dam örtü kiriş ve merteklerinde kullanılmıștır. Tuğla; mihrap kemer yapımında kullanılmıştır. Metal; kapı ve pencere aksesuarlarında ve pencere korkulularında kullanılmıştır.

\subsection{Harç ve Sıva Analiz Sonuçları}

Abbasağa Camii'nin taş duvar imalat yapımında bağlayıcı olarak kireç harcı, kerpiç duvarlarında ise odun külü, saman, kaya tuzu katkılı çamur kullanılmıştır. Moloz taş duvar yapımındaki kireç harç ve sıva numunesi iki farklı yerden alınarak laboratuvar kimyasal analizleri yapılmıştır (Şekil 66,67).

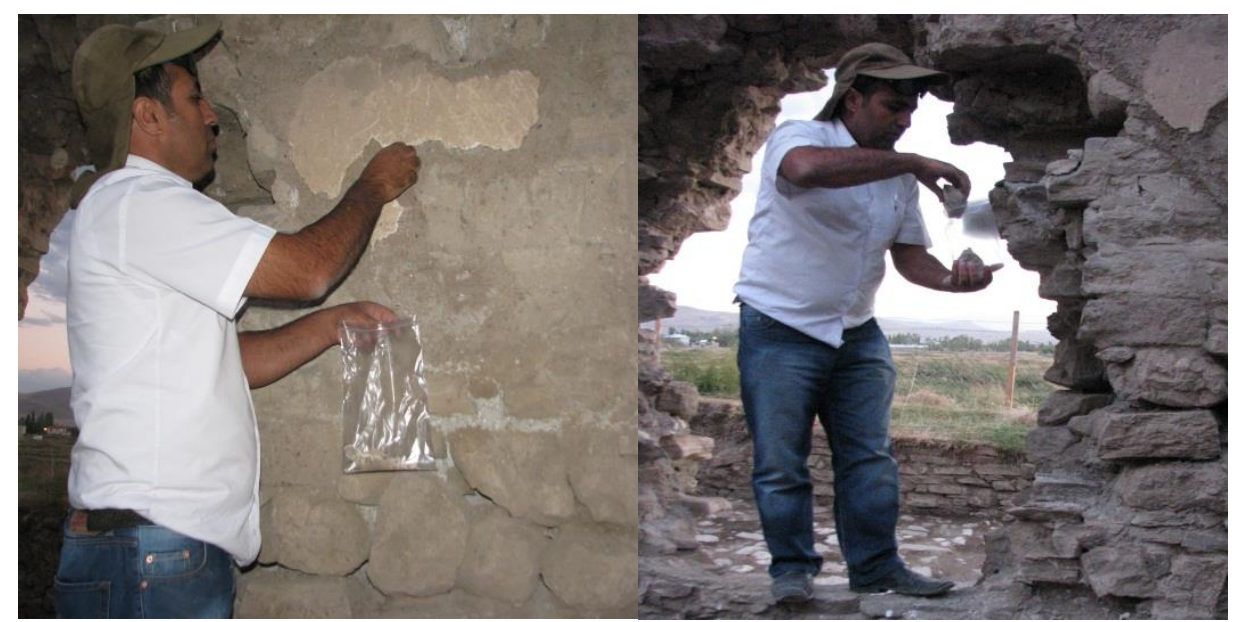

Şekil 66 ve Şekil 67. Harç ve Siva Numunesi Alma Görünüşleri (Ş. Öztürk)

Kültür ve Turizm Bakanlığ1 İstanbul Restorasyon ve Konservasyon Merkez ve Bölge Laboratuvarı Müdürlüğü'nün 28.06.2014 tarih 703 sayılı Van Abbasağa Camii sıva ve harç analiz rapor sonuçları yapılarak tamamlanmıştır. 
Abbasağa Camii’nde alınan iki sıva numunesi; Krem renkte, yumuşak dokulu gözeneksiz görünen ince agregalı ince sıva tabakası dağılganlığı az, elle kolayca parçalanabilir niteliktedir. Malzeme Dayanımı; Dağılganlığı elle kolayca parçalanabilir.

Abbasağa Camii'nden alınan iki harç numunesi; Gri renkte, yumuşak dokulu, kısmen gözenekli, yer yer kireç lumpları içere, görünen ince agregalı harç niteliğindedir. Sert ve sağlam, elle koparılabilir, fakat dağılmaz özelliktedir. Malzeme Dayanımı; Sert ve sağlam, elle koparılabilir fakat dağılmaz.

\subsection{Kimyasal Analizler}

Malzeme içindeki kireç (Kalsiyum Karbonat), organik madde ve nem miktarlarını tespit etmek amacıyla yapılan analizlerdir. Malzeme içindeki kireç oranının tespiti için; kızdırma kaybı (kalsinasyon) ile asit testi (HGI2de Kayıp) analizleri yapılmıștır. Kızdırma kayıpları analizleri sonucunda bulunan değerler malzeme içindeki organik madde miktarını ve kalsiyum karbonat miktarını verir. Asit testi sonucu ise malzemedeki kalsiyum karbonat miktarını verir.

Aşağıda; kızdırma kayıpları, asit testi, elek analizleri ve spot test sonuçları verilmiştir.

Önerilen sıva analiz karışım oranları; \%33-35 Sönmüş ve bekletilmiş kireç, \%33-35 Taş tozu, \%28-30

Yıkanmıs ince dere kumu

Önerilen harç analiz karışım oranları; \%32-33 Sönmüş ve bekletilmiş kireç, \%28-30 Taş tozu, \%35-37 Yıkanmış ince dere kumu

\section{Süsleme}

Abbasağa Camii, iç ve dış mimari öğeleri bakımından son derece yalın olup mimari süsleme kullanılmamıştır.

\section{Proje Uygulamaları}

Abbasağa Camii, kazı ve temizlik çalışmaları yapılmadan önce 2008 yılında Van Valiliği ìl Özel İdare Sekreterliği tarafından yapılan rölöve, restitüsyon ve restorasyon çalışmaları Van Kültür Varlıkları Bölge Müdürlüğü tarafından onaylanmıştır.

Vakıflar Genel Müdürlüğü Bitlis Vakıflar Bölge Müdürlüğü tarafindan 2012 yılında kazı, temizlik ve onarım ihalesi sonrası yapılan kazı ve temizlik çalışmalarından sonra yeniden uygulama projeleri hazırlanmıştır. Projeler Yüzüncü Yıl Üniversitesi Mühendislik-Mimarlık Fakültesi Mimarlık Bölümü Restorasyon Anabilim Dalı Başkanı Dr. Öğretim Üyesi (Mimar-Sanat Tarihçisi) Şahabettin Öztürk tarafından hazırlanmıştır.

Projeler;

\section{a. Rölöve}

a.1. Rölöve Hasar Analiz Projesi

a.2. Rölöve Malzeme Analiz Projesi

a.3. Analitik Analiz Projesi

\section{b. Restitüsyon}

b.1. Mevcut Yapı Bölümleri (Özgün Yapı Doku)

b.2. Mevcut Yapı İzleri İle Tamamlana Yapı Bölümleri

b.3. Bölgedeki Yapılar İle Karşıllaştırma Yapılarak Tamamlanan Yapı Bölümleri

b.4. Mimari Gereklilikle Tamamlana Yapı Bölümleri

\section{c. Restorasyon}

c.1. Restorasyon Projesi 
c.2. Restorasyon Müdahale Projesi

\section{d. Raporu ve Fotoğraf}

d.1. Koruma Raporu

d.2. Fotoğraf Albümü

\section{Sonuc}

Eski Van Şehri ve Van Kalesi konum ve stratejik yapısından dolayı, eski çağlardan günümüze kadar birçok uygarlık tarafından kullanılmıştır. Her uygarlık dini, askeri ve sivil mimarlık eserleri ile kadim olan şehri adeta süslemiştir. Kuşkusuz bu önemli kente hayat veren dini mimari yapıların rolü oldukça büyüktür.

Abbas Ağa Camii, sadece cami olarak değil aynı zamanda medrese olarak da kullanılmış dini bir yapıdır. Özellikle cami içerisindeki yonu taştan imal edilmiş oturma sekileri istisnai bir mimari eleman olarak karşımıza çıkar. Caminin ibadet faaliyetlerinin dışında diğer sosyal amaçlı faaliyetlerde de kullandığının bir kanıtıdır. Abbas Ağa Camii, kerpiç malzeme, çamur sıva yardımıyla inşa edilen beden duvarlarının iç bölümlerine yerleştirilen aks-i seda küpleri ve düz toprak dam sistem ve yapım teknikleri bakımından bölgedeki diğer dini mimari yapılardan oldukça farklı mimari özelliklere sahiptir.

Son y1llarda Eski Van Şehri'nde ve Van Kalesi'nin kuzeyinde yılın sadece bir ayında yapılan bilimsel kazı çalışmaları, doğanın ve definecilerin olumsuz etkisi altında kalarak yok olmaktadır. Vakıflar Genel Müdürlügü Bitlis Vakıflar Bölge Müdürlügü tarafından onarımı yapılan Kaya Çelebi Camii, Hüsrev Paşa Külliyesi, Horhor Camii, Süleyman Han Camii ve günümüzde yerli ve yabanc1 turistler tarafindan kullanılan dini yapılar mevcuttur.

Onarım çalışmaları devam eden başta Abbas Ağa Camii, Ulu Cami, Kızıl Camii gibi yapıların, onarımı tamamlandığında yaklaşık bir asır boyu adeta ölü bir kent olan Eski Van Şehri'ne canlılık kazndıracağı bir gerçektir. Bu durum ise bölge kültür ve turizmine önemli kazanımlar sağlayacaktır.

\section{KAYNAKÇA}

Günel, F. M. (1993). Eski Van Kent Dokusu Üzerine Bir Deneme. (Yayımlanmamış yüksek lisans tezi). Yüzüncü Yıl Üniversitesi Sosyal Bilimler Enstitüsü Arkeoloji ve Sanat Tarihi Anabilim Dalı, Van.

Öztürk, Ş. ve Mızrak, A. (2001). Eski Van Şehir Surları, Mimarlık İ̧ Mimarlık ve Görsel Sanatlar Dergisi, 102, 32-34.

Öztürk, Ş. (2004). Mimarlık ve Kent, Turkuaz: Denizin Coğrafyasında Van Eski Van: Şehri, TMMOB Mimarlık Dergisi, 317, 52-54.

Öztürk, Ş. (1996). Van-Ahlat ve Adilcevaz Tarihi Camileri Rölöve Proje Çalışması. (Yayımlanmamış yüksek lisans tezi). Yüzüncü Y1l Üniversitesi Sosyal Bilimler Enstitüsü, Van. 